\title{
Developed Country Trade Barriers and the Least Developed Countries: The Current Situation
}

\author{
Jon D. Haveman and Howard J. Shatz \\ Public Policy Institute of California
}

\begin{abstract}
In the 2001 Doha Development Round ministerial declaration, countries committed themselves "to the objective of duty-free, quota-free market access for products originating from LDCs." In this light, this paper investigates the current tariff barriers put in place and preferences granted by the Triad countries regarding products from LDCs. It first investigates preferences in policy-the simple average tariffs faced by LDCs-and then looks at barriers in practice, analyzing the extent to which LDCs have been able to take advantage of the variety of preferences granted. It also explores the LDC tariff barriers against goods from other countries. It finds that Triad tariff barriers against $L D C$ products have fallen dramatically and are especially low in the EU. However, barriers remain against certain products in which LDCs specialize, so that U.S. import-weighted tariffs for LDC goods are actually higher than U.S. import-weighted tariffs for goods of countries subject to MFN tariffs. Furthermore, the LDCs themselves tend to favor goods from the advanced industrial countries. These results indicate that there is still much room for tariff reductions for LDC goods, especially in the United States, and that such reductions must take account of LDC production capabilities.
\end{abstract}

- JEL Classifications: F1, F13, F14, O1

- Key words: Least developed countries, Generalized system of preferences, Unilateral preference programs, Doha round

\footnotetext{
*Corresponding address: Public Policy Institute of California, 500 Washington St., Suite 800, San Francisco, CA 94111, USA Tel: +01-415-291-4439, 4409 Fax: +01-415-291-4401,4428, E-mail: haveman@ppic.org,shatz @ppic.org (C2004-Center for International Economics, Sejong Institution, All Rights Reserved.
} 


\section{Introduction}

The official agenda of the current World Trade Organization negotiations concentrates on developing countries, giving this ninth negotiating round the moniker the "Doha Development Round." In the work program laid out by the 20 November 2001 ministerial declaration kicking off the round, the negotiating countries committed themselves "to the objective of duty-free, quota-free market access for products originating from LDCs [Least Developed Countries]" (paragraph 42, page 9). ${ }^{1}$ Based on the intention of removing barriers to LDC trade, this paper investigates the trade barriers that currently face the poor countries of the world. A companion paper (Haveman and Shatz, 2004) examines episodes of trade liberalization for goods of poor countries and speculates on how liberalization might change the trade patterns of both developing and developed (importing) countries.

This paper serves as a tour of the world of trade barriers and preferences, investigating the barriers put in place and preferences granted by the Triad members United States, European Union, and Japan against products from developing and least developed countries. Though the country focus is on the 49 least developed countries, listed in Appendix A, the paper analyzes the wider set of all developing countries as well. The trade policy focus is on tariffs, and the discussion excludes non-tariff barriers, which may present similar or different conclusions as tariff barriers.

The paper is organized in seven sections, including the introduction. The next section discusses the nature and institutional background of current preferential policies on the part of the Triad as they pertain to developing and least developed countries. The third section analyzes the preferences in policy, showing the tariff preferences offered by the Triad members without taking account of how developing countries take advantage of these preferences. The fourth section examines the preferential policies in practice. In particular, by taking account of actual trade flows, we provide insight into the generosity of the programs of each Triad member. The fifth section continues the theme of the fourth, but focuses the exercise by touching on the benefits as they are distributed to different regions of the world. The penultimate section turns the tables and explores tariff barriers imposed by the least developed nations, and a final section concludes.

\footnotetext{
${ }^{1}$ WTO, 2001
} 


\section{Description of Programs}

\section{A. The Generalized System of Preferences}

The idea of granting special treatment to least developed countries is not new, though it has gained momentum in the last decade. Most of the advanced industrial countries now unilaterally grant preferences to developing countries, and many grant enhanced preferences to LDCs.

The most widespread preference program is the Generalized System of Preferences (GSP). This program became legal under the General Agreement on Tariffs and Trade (GATT) with the passage of the so-called "enabling clause" on 25 June 1971. Under GATT Article I, members had to grant most-favored nation (MFN) treatment to all signatories, giving all GATT trading partners the same treatment as the partner receiving the best treatment and creating a problem for special preference programs. With the enabling clause, the GATT contracting parties agreed to waive Article I for 10 years so that developed GATT members could institute preferential programs for developing countries. The clause was extended indefinitely on 28 November 1979. Currently 15 economies offer GSP programs, as shown in Table 1. Austria, Finland, and Sweden offered their own programs before joining the European Union in 1995. These programs cover nearly every developing country in the world, and some offer special preferences for LDCs. The programs offer zero-duty or reduced-duty entry to goods from eligible countries, as determined by the granting countries. The tariff preferences and the lists of eligible products and countries have been broadened over time by the preference-granting countries.

GSP programs, though generous, are not without strings attached. First, since they are unilaterally granted, they can be unilaterally revoked, leading to uncertainty. Second, GSP programs do not necessarily cover the full range of goods for which developing countries might desire preferential market access. Third, programs also have specific rules of origin, which can be difficult for developing countries to fulfill, and fourth, they often feature competitive needs limits, in which a country is prohibited from exporting too much under the program. Not many countries have run afoul of these limits. 
Developed Country Trade Barriers and the Least Developed Countries: The Current Situation 233

Table 1. Countries offering unilateral concessions under the generalized system of preferences

\begin{tabular}{ccc}
\hline Australia & European Union & Poland \\
\hline Belarus & Hungary & Russian Federation \\
\hline Bulgaria & Japan & Slovak Republic \\
\hline Canada & New Zealand & Switzerland \\
\hline Czech Republic & Norway & United States \\
\hline
\end{tabular}

\section{B. Specific Preference Programs in the Triad}

\section{The United States}

Through its GSP program, the United States currently offers preferences to 123 independent countries and 19 non-independent countries and territories. Members of five country groupings, such as the West African Economic and Monetary Union, are considered as one country for purposes of rules of origin and other GSP regulations. This program offers special terms to LDCs. In particular, competitive needs limits do not apply to LDCs and better trading terms are offered on an additional 1,770 products that have been designated as duty-free exclusively for the least developed countries. The beneficiary list does not include all LDCs, and UN-designated LDCs are not necessarily included as US-designated LDCs. The UN-designated LDCs not included in the US GSP program include Afghanistan, Laos, Liberia, Myanmar, and Sudan.

The oldest regional preference program the United States sponsors is the Caribbean Basin Economic Recovery Act (CBERA), also known as the Caribbean Basin Initiative (CBI). In 2000, the US added the Caribbean Basin Trade Partnership Act (CBTPA) to its arsenal of preferences for the Caribbean and Central America. The CBTPA essentially extended benefits to the Caribbean similar to the benefits Mexico gained from the reciprocal North American Free Trade Agreement, where NAFTA benefits are greater than CBERA preferences. Most importantly, the CBTPA includes a range of textile and apparel products, though with rules-of-origin requirements. CBTPA benefits are set to expire on 30 September 2008 or with the completion of a Free Trade Area of the Americas agreement, whichever comes first.

Nearly all the countries of the Caribbean, including those of Central America, participate in the Caribbean unilateral initiatives. All countries receiving CBERA benefits also receive CBTPA benefits. Table 2 shows these beneficiary countries, which include Haiti, the only LDC in the Western Hemisphere. 
Table 2. Caribbean trade preference beneficiary countries

\begin{tabular}{ccc}
\hline Antigua and Barbuda & Dominican Republic & Montserrat \\
\hline Aruba & El Salvador & Netherlands Antilles \\
\hline The Bahamas & Grenada & Nicaragua \\
\hline Barbados & Guatemala & Panama \\
\hline Belize & Guyana & Saint Kitts and Nevis \\
\hline British Virgin Islands & Haiti & Saint Lucia \\
\hline Costa Rica & Honduras & Saint Vincent and the Grenadines \\
\hline Dominica & Jamaica & Trinidad and Tobago
\end{tabular}

Source: Office of the United States Trade Representative, 1999.

The United States also maintains unilateral preferences for the Andean countries through the Andean Trade Preferences Act (ATPA). The ATPA beneficiary countries include Bolivia, Colombia, Ecuador, and Peru, none of which are classified as LDCs. These benefits have recently been extended through the end of 2006. This extension also broadened product coverage to include apparel, though again only under certain conditions.

The final regional program is the African Growth and Opportunity Act, approved in 2000 and effective in the last month of that year. AGOA is different from the US GSP program in a number of ways. First, whereas GSP preferences are renewed annually, AGOA locks in GSP preferences for beneficiary countries for eight years, until 30 September 2008. It also adds 1,835 new products to the GSP list specifically for AGOA beneficiaries. In addition, it removes the competitive needs limits that apply to countries other than LDCs in the GSP program. Finally, it includes benefits for textiles and apparel provided beneficiaries show they have procedures in place to prevent transshipments. This essentially creates two tiers of beneficiaries - regular beneficiaries and beneficiaries cleared to export textiles and apparel to the United States. Table 3. shows AGOA beneficiaries, with an asterisk indicating those qualifying for textile and apparel benefits.

\section{The European Union}

The European Union (then the European Economic Community) was the first economy to implement a generalized system of preferences after such a system had been allowed by the GATT. Unlike the GSP program of the United States, when the EU offers a preference it does not necessarily take the form of duty-free market access. Instead, in its current edition, good for 2002-2004, the EU 
Developed Country Trade Barriers and the Least Developed Countries: The Current Situation 235

Table 3. African growth and opportunity beneficiary countries

\begin{tabular}{ll}
\hline Benin & Madagascar* \\
Botswana* & Malawi* \\
Cameroon* & Mali \\
Cape Verde* & Mauritania \\
Central African Republic & Mauritius* \\
Chad & Mozambique* \\
Republic of Congo & Namibia* \\
Côte d'Ivoire & Niger \\
Djibouti & Nigeria \\
Eritrea & Rwanda* \\
Ethiopia* & Sao Tome and Principe \\
Gabon & Senegal* \\
Gambia & Seychelles \\
Ghana* & Sierra Leone \\
Guinea & South Africa* \\
Guinea-Bissau & Swaziland* \\
Kenya* & Tanzania* \\
Lesotho* & Uganda* \\
Liberia & Zambia* \\
\hline Indicates countries qualifying for textile and apparel benefits as of March 2003. \\
\end{tabular}

designates two types of goods, non-sensitive and sensitive. The non-sensitive goods enter the EU at zero duty, while the sensitive enter at a duty that is positive, but lower than the MFN rate. ${ }^{2}$ The EU GSP has long included favorable treatment for least developed countries. It now offers more favorable benefits to a number of different types of countries. These include countries that have taken special steps to promote labor rights, countries that have taken special steps to protect their tropical forests, and countries combating drug production and trafficking. The most favorable arrangements, however, are reserved for least developed countries through the new Everything But Arms (EBA) initiative. ${ }^{3}$

Effective 1 March 2001, the EU allowed duty-free and quota-free access to all products from LDCs except arms and ammunition (Harmonized System chapter 93), and bananas, sugar, and rice. ${ }^{4}$ All three are to be liberalized in stages, with

\footnotetext{
${ }^{2}$ European Union (1999 and 2002).

${ }^{3}$ See Cernat et al. (2004) for more on EBA.

${ }^{4}$ The EU has been offering duty-free market access on all categories of arms and ammunitions to participants in its program for African, Caribbean, and Pacific countries for some time.
} 
bananas to be duty-free by 1 January 2006, sugar to be duty-free by 1 July 2009 , and rice to be duty-free by 1 September 2009. Rules of origin, documents, and other requirements of the GSP program still apply, though unlike other GSP benefits, the EBA program has no expiration date. The EU currently offers GSP benefits to 179 countries and territories. It extends LDC benefits (EBA) to all 49 of the United Nations-designated least developed countries.

In addition to the GSP, the EU also offers benefits to its former colonies in Africa, the Caribbean, and the Pacific through the ACP-EC Agreement, also known as the Cotonou Agreement, signed in 2000..$^{5}$ This agreement is a successor to the Lomé Convention, which went through four different revisions between 1975 and 2000.

Currently, 77 countries are beneficiaries under the Cotonou Agreement, as shown in Table 4. These include all LDCs except those in Asia and the Middle East (Afghanistan, Bangladesh, Bhutan, Cambodia, Laos, Myanmar, Maldives, Nepal, and Yemen). The Agreement is to last 20 years, with revisions every five years. Benefits to non-LDC countries under Cotonou are more generous than under the GSP.

\section{Japan}

Japan's sole preference program is the GSP, offering benefits on a positive list of 226 agricultural products (harmonized tariff system chapters 1 through 24) and all industrial products (chapters 25 through 97) except for a negative list of 105 items. As is the case for the EU, the program is not a blanket duty-free system. Tariffs on agricultural products range from zero to a reduction of the MFN rate, while tariffs on industrial products are zero except for so-called sensitive items, which have a value or quantity ceiling. ${ }^{6}$ Tariffs on these items are either zero or some proportion of the MFN rate.

The program currently extends benefits to 149 countries and 15 territories, and extends LDC benefits to all but two of the 49 United Nations-designated LDCs (Comoros and Djibouti have not applied for benefits under the GSP program). These special benefits extend duty-free treatment to all products covered by the GSP and eliminate ceilings except for special rules applying to copper from the Democratic Republic of Congo and Zambia.

\footnotetext{
${ }^{5}$ This agreement entered into force 1 April 2003.

${ }^{6}$ Sensitive items include 1,181 products in 81 product groups.
} 
Developed Country Trade Barriers and the Least Developed Countries: The Current Situation 237

Table 4. Cotonou agreement beneficiary countries

\begin{tabular}{|c|c|}
\hline Angola & Malawi \\
\hline Antigua and Barbuda & Mali \\
\hline The Bahamas & Marshall Islands \\
\hline Barbados & Mauritania \\
\hline Belize & Mauritius \\
\hline Benin & Federated States of Micronesia \\
\hline Botswana & Mozambique \\
\hline Burkina Faso & Namibia \\
\hline Burundi & Nauru \\
\hline Cameroon & Niue \\
\hline Cape Verde & Niger \\
\hline Central African Republic & Nigeria \\
\hline Chad & Palau \\
\hline Comoros & Papua New Guinea \\
\hline Congo (Brazzaville) & Rwanda \\
\hline Congo (Kinshasa) & Saint Kitts and Nevis \\
\hline Cook Islands & Saint Lucia \\
\hline Côte d'Ivoire & Saint Vincent and the Grenadines \\
\hline Djibouti & Samoa \\
\hline Dominica & Sao Tome and Principe \\
\hline Dominican Republic & Senegal \\
\hline Equatorial Guinea & Seychelles \\
\hline Eritrea & Sierra Leone \\
\hline Ethiopia & Solomon Islands \\
\hline Fiji & Somalia \\
\hline Gabon & South Africa \\
\hline Gambia & Suriname \\
\hline Ghana & Sudan \\
\hline Grenada & Swaziland \\
\hline Guinea & Tanzania \\
\hline Guinea-Bissau & Togo \\
\hline Guyana & Tonga \\
\hline Haiti & Trinidad and Tobago \\
\hline Jamaica & Tuvalu \\
\hline Kenya & Uganda \\
\hline Kiribati & Vanuatu \\
\hline Lesotho & Zambia \\
\hline Liberia & Zimbabwe \\
\hline Madagascar & \\
\hline
\end{tabular}


Japan's 99 Percent Initiative of 1 April 2001 goes even further. Japan added about 360 items duty-free and quota-free to the GSP list exclusively for least developed countries. ${ }^{7}$ By the estimate of the Ministry of Economics, Trade, and Industry, this increased to 99 percent (from around 94 percent) the share of industrial products granted duty-free, quota-free access from LDCs. New products included all textile and apparel items. All LDCs are eligible, but must apply.

\section{Triad Preferences in Policy}

When we discuss preferences in policy, we refer to the doors that are opened by the reduction or elimination of barriers to imports into one of the Triad members. This notion is distinct from preferences in practice, which refers more directly to how much in the way of LDC exports get pushed through the opened door. In this section, we explore the generosity of Triad tariff preferences in policy, saving the more important question of practice for the next section.

In order to capture the nature of preferences in policy, we focus our calculations on simple average tariffs for the United States, the European Union, and Japan. Table 5 provides detail regarding the recent history of Triad tariffs and developing country preferences for programs offered through $2000 .^{8}$ The table is broken vertically into panels for each country and horizontally into panels for each of the three years: 1993, 1996, and 2000. This horizontal and vertical breakdown results in nine panels, one for each country and year. In each panel, the first column gives the simple average tariff across lines in each countrys tariff schedule. The second column indicates, for each countrys preference programs, the percent of tariff lines that grant some benefit to a recipient country. Finally, the third column indicates the percent of tariff lines in each schedule that have no tariff.

The rows in each panel correspond to the tariffs that apply to trade partners eligible for each program. The United States, for instance, has four unilateral tariff preference schemes that in one way or another benefit developing or least developed countries (as of 2000). These programs are the Generalized System of Preferences (GSP), the Generalized System of Preferences for Least Developed Countries (GSPLDC), the Caribbean Basin Economic Recovery Act (CBERA),

\footnotetext{
${ }^{7}$ Ministry of Economics, Trade, and Industry (2000) and Ministry of Foreign Affairs (undated).

${ }^{8}$ All three Triad members either enhanced their programs or added new programs in late 2000 and 2001, as described in the previous section. Comprehensive data on these programs are not yet available.
} 
Developed Country Trade Barriers and the Least Developed Countries: The Current Situation 239

Table 5. The extent of triad preferences for developing countries

\begin{tabular}{|c|c|c|c|c|c|c|c|c|c|}
\hline & \multicolumn{3}{|c|}{1993} & \multicolumn{3}{|c|}{1996} & \multicolumn{3}{|c|}{2000} \\
\hline & \multirow{2}{*}{$\begin{array}{c}\text { Simple } \\
\text { Average } \\
\text { Tariff }\end{array}$} & \multicolumn{2}{|c|}{ Percent } & \multirow{2}{*}{$\begin{array}{c}\text { Simple } \\
\text { Average } \\
\text { Tariff }\end{array}$} & \multicolumn{2}{|c|}{ Percent } & \multirow{2}{*}{$\begin{array}{c}\text { Simple } \\
\text { Average } \\
\text { Tariff }\end{array}$} & \multicolumn{2}{|c|}{ Percent } \\
\hline & & $\begin{array}{c}\text { With } \\
\text { Benefit }\end{array}$ & Zero & & $\begin{array}{c}\text { With } \\
\text { Benefit }\end{array}$ & Zero & & $\begin{array}{c}\text { With } \\
\text { Benefit }\end{array}$ & Zero \\
\hline \multicolumn{10}{|l|}{ US } \\
\hline MFN & 6.37 & & 16.6 & 6.72 & & 17.9 & 4.62 & & 35.2 \\
\hline GSP & 3.61 & 50.4 & 67.0 & 4.72 & 46.1 & 64.0 & 3.10 & 34.8 & 70.1 \\
\hline GSPLDC & & & & & & & 2.15 & 48.4 & 83.7 \\
\hline CBERA & 1.87 & 70.5 & 86.6 & 2.95 & 68.7 & 84.3 & 1.83 & 53.0 & 85.8 \\
\hline ATPA & 1.87 & 70.5 & 86.6 & 3.13 & 66.9 & 86.1 & 1.99 & 51.1 & 87.8 \\
\hline $\mathrm{N}$ & & 7,503 & & & 10,081 & & & 8,891 & \\
\hline \multicolumn{10}{|l|}{$\mathrm{EU}$} \\
\hline MFN & 7.41 & & 10.3 & 5.99 & & 15.1 & 4.77 & & 23.8 \\
\hline GSP & 2.84 & 67.5 & 75.0 & 3.44 & 76.6 & 45.7 & 2.71 & 72.1 & 58.2 \\
\hline GSPLDC & 0.76 & 83.1 & 93.4 & 1.36 & 79.8 & 87.0 & 0.06 & 75.6 & 99.3 \\
\hline $\mathrm{ACP}$ & 0.34 & 87.8 & 97.8 & 0.12 & 84.4 & 98.6 & 0.07 & 76.1 & 99.1 \\
\hline $\mathrm{N}$ & & 8,876 & & & 9,467 & & & 9,370 & \\
\hline \multicolumn{10}{|l|}{ Japan } \\
\hline MFN & 18.44 & & 8.9 & 6.59 & & 36.1 & 6.58 & & 36.2 \\
\hline GSP & 8.83 & 49.7 & 43.8 & 3.46 & 47.5 & 69.0 & 3.37 & 47.5 & 69.0 \\
\hline GSPLDC & 7.66 & 50.2 & 59.1 & 2.39 & 47.8 & 83.8 & 2.40 & 47.5 & 83.7 \\
\hline $\mathrm{N}$ & & 8,334 & & & 8,619 & & & 8,522 & \\
\hline
\end{tabular}

Source: Authors' calculations from various versions of the UNCTAD-TRAINS dataset.

and the Andean Trade Preference Act (ATPA). ${ }^{9}$ Each of these preference programs, with the exception of the GSPLDC scheme, was in place in 1993. The European Union and Japan have similar GSP and GSPLDC programs. In addition, the European Union grants significant unilateral preferences to its former colonies through the Cotonou Agreement, denoted as ACP in the table. The final line of each panel shows the number of tariff lines in each Triad member's tariff schedule.

Turning first to the country group that receives only Most Favored Nation, or MFN, tariffs, it is clear that the 1990 s were a period of significant tariff reductions

\footnotetext{
${ }^{9}$ The GSP for LDCs is not actually a separate program, but offers increased benefits for LDCs under the GSP. This is how the EU and Japan GSP programs work as well.
} 
for each of the Triad members. The most dramatic decline took place in the Japanese tariff schedule, with simple average tariffs falling from 18.44 to 6.59 percent. The United States and European Union also reduced their tariffs by two to three percentage points. For each of these countries, these reductions included the zeroing out of a significant number of tariffs. Both the United States and the EU doubled the share of tariff lines with zero tariffs while Japan increased the number of zero tariffs by fourfold, from 9 percent to just over 36 percent.

Though a period of significant tariff reductions for each of the members of the Triad, the pattern of liberalization differs significantly between the three. The United States, for instance, saw an increase in its simple average tariff between 1993 and 1996 and then a significant decrease between 1996 and 2000. The European Union steadily reduced its tariffs throughout the 1993-2000 period, while Japan's tariff declines were largely implemented between 1993 and 1996.

Performing the same temporal comparisons for tariffs imposed on goods from developing and least developed countries, one sees changes that are much smaller. In particular, for the United States, simple average tariffs for the CBERA and ATPA countries were largely unchanged between 1993 and 2000. In the intervening years, the generosity of the programs in fact declined significantly between 1993 and 1996, recovering in the last half of the decade. The United States initiated extra benefits for LDCs under the GSP in 1997 by granting them duty free access for an additional 13.6 percent of U.S. import product categories, effectively lowering tariffs to imports from LDCs by almost a full percentage point compared to tariffs imposed on goods from countries eligible for the regular GSP.

The European Union and Japan both increased the generosity of their programs for LDCs during the 1990s. The EU all but eliminated tariffs under its GSPLDC and ACP programs, leaving tariffs in less than one percent of all categories, but again after a decline in generosity in the middle of the decade. In Japan, tariffs imposed on imports from LDCs declined from 7.66 percent on average in 1993 to 2.4 percent in 2000. In contrast to the United States and EU, most of this change occurred between 1993 and 1996, with little or no change in the rest of the decade. In addition to a general lowering of tariffs, there was an increase of almost 25 percentage points in the number of products that Japan was willing to import from LDCs free of duties.

Also worthy of note is the fact that the share of tariff lines on which LDCs were granted some preference declined in all three countries. However, this change can 
be almost entirely explained by the declining number of lines in the MFN schedules of each country that retain some positive duty. As more and more MFN tariffs are eliminated, the share of tariff lines for which a preference is possible also declines.

We have so far provided an indication of the temporal changes in average preferences across preference schemes. Exploring the pattern of preferences granted across commodities gives additional insights. The first three columns of Table 6 indicate the industrial distribution of preferences for LDCs as granted by each of the Triad members. The extent of preferences granted in any commodity category is measured by the fraction of tariff lines in the category to which preferential access is granted. The table reflects preferences as they were granted

Table 6. Industrial Distribution of Triad Preferences for LDCs, 2000

\begin{tabular}{|c|c|c|c|c|c|c|}
\hline & \multicolumn{3}{|c|}{$\begin{array}{l}\text { Proportion of HS } \\
\text { Codes } \\
\text { With a Preference }\end{array}$} & \multicolumn{3}{|c|}{$\begin{array}{c}\text { Proportion of HS Codes } \\
\text { With a Positive MFN Tariff } \\
\text { With a Preference }\end{array}$} \\
\hline & US & EU & Japan & US & $\mathrm{EU}$ & Japan \\
\hline Animal or Veg. Fats, Oils \& Waxes & 0.52 & 0.81 & 0.28 & & & 0.365 \\
\hline Animals \& Animal Products & 0.45 & 0.73 & 0.06 & 0.946 & & 0.080 \\
\hline Arms \& Ammunition & 0.40 & 0.93 & 1.00 & & & \\
\hline Articles of Stone, Plaster, Cement & 0.60 & 0.86 & 0.38 & 0.951 & & \\
\hline Base metals \& Articles thereof & 0.80 & 0.89 & 0.67 & & & 0.998 \\
\hline Chemical Products & 0.68 & 0.76 & 0.70 & & & 0.998 \\
\hline Footwear, Headgear & 0.22 & 0.98 & 0.75 & 0.342 & & 0.794 \\
\hline Hides \& Skins & 0.51 & 0.67 & 0.57 & & & 0.813 \\
\hline Instruments & 0.55 & 0.69 & 0.02 & & & 0.867 \\
\hline Machinery \& Mechanical Appliances & 0.46 & 0.72 & 0.02 & & & \\
\hline Mineral Products & 0.06 & 0.21 & 0.11 & & & 0.700 \\
\hline Miscellaneous & 0.48 & 0.84 & 0.57 & 0.995 & & \\
\hline Plastics \& Rubber & 0.77 & 0.81 & 0.75 & 0.998 & & \\
\hline Precious Stones, Metals, Coins & 0.53 & 0.23 & 0.26 & & & \\
\hline Prepared Foodstuffs & 0.64 & 0.80 & 0.31 & 0.900 & 0.996 & 0.346 \\
\hline Textiles \& Textile Articles & 0.07 & 0.96 & 0.81 & 0.317 & & 0.854 \\
\hline Transportation Equipment & 0.51 & 0.88 & 0.01 & & & \\
\hline Vegetable Products & 0.44 & 0.61 & 0.21 & 0.981 & 0.985 & 0.302 \\
\hline Wood \& Wood Products & 0.38 & 0.57 & 0.52 & & & 0.859 \\
\hline Wood Pulp \& Products & 0.56 & 0.76 & 0.59 & & & \\
\hline Works of Art, Collector's Pieces \& Antiq ${ }^{10}$ & 0.00 & 0.00 & 0.00 & & & \\
\hline
\end{tabular}

\footnotetext{
${ }^{10}$ None of the Triad members impose tariffs in this sector.
} 
in 2000 .

Viewing the preferences in this way serves to illustrate different priorities inherent in the policies adopted by the Triad. In particular, the United States is loath to grant preferences on textiles and related products, such as footwear and headgear. These same categories show up as among the most favored for preferences by both the European Union and Japan. In addition, the United States grants relatively few preferences for Arms and Ammunition, while the EU and Japan grant near duty free access for all types of weapons. ${ }^{11}$ The EU preferences run deep almost uniformly. Only three sectors have preferences on less than 50 percent of the underlying tariff lines. Japan, on the other hand, is less generous in almost every category, with slightly less than half of all sectors granting preferential access to 50 percent or more of the underlying tariff lines.

This is, of course, just one way of analyzing the extent of Triad preferences in policy. The tables in Appendix B take another approach by showing the simple average tariff for each of 212 -digit Harmonized System tariff categories. For each Triad member, a separate table includes average MFN tariffs and average tariffs imposed on goods imported from the countries eligible for each of the unilateral preference schemes. The observations from Table 6 are borne out in these data. ${ }^{12}$ U.S. tariff preferences run deep in some sectors, in particular, Transportation Equipment and Plastics and Rubber, and less deep in others, such as Footwear and Headgear and Textiles and Textile Apparel. Preferences run uniformly deep for the European Union and are reasonably shallow for most heavily protected sectors in Japan, with the notable exception of Textiles and Textile Articles, for which LDC exports face tariffs that are less than 10 percent of the MFN tariffs.

The entries in columns 4-6 of Table 6 present the same statistic as in columns 1-3, but restrict the basis to all HS product codes in each sector that have an MFN tariff greater than zero. In order to highlight sectors in which preferences have been withheld, in columns 4-6 we have deleted entries where some preference is granted to all $\mathrm{HS}$ product codes in a sector, so that blanks indicate 100 percent coverage. These last three columns, therefore, provide evidence of the extent to which the Triad members provide preferential market access when they are able.

\footnotetext{
${ }^{11}$ Note that for the EU, these preferences only apply to ACP countries and not to other LDCs.

${ }^{12}$ Table 6 gives the proportion of HS codes that have a unilateral preference for LDCs associated with them. Appendix C presents columns 1-3 of Table 6 for all unilateral preference programs combined. This includes CBERA and ATPA preferences for the United States. The figures presented there are not significantly different, but are somewhat higher in many cases.
} 
In cases where the MFN tariff is already zero, no preference can be granted.

What is immediately striking is the number of entries that have been dropped. In particular, the EU provides preferences for nearly every product in nearly every sector. In the two sectors where it does not provide preferences for every product Vegetable Products and Prepared Foodstuffs -- it fails to provide preferences for only a very small fraction of the product codes. The United States also provides broad access, failing to provide complete preference coverage in a little more than one third of these sectors. In some cases, clothing and textile categories, preferences are granted sparingly. As we have already seen, Japan's preferences are less generous than those of both the United States and the European Union, with preferential treatment being withheld in a broad range of sectors. The most significant proportion of barriers remains in food related sectors, most notably Animals and Animal Products, and Vegetable Products.

These patterns of protection are not surprising. The United States has a long history of protecting textiles industries and the European Union and Japan have long focused their protection on their agricultural sectors. This may in part be due to political economy issues. The textile industry in the United States is concentrated in just a few southern states, leading political, industry, and labor officials from those states to fight ferociously for federal favors. Likewise, in Europe and Japan, a small number of farmers gain from generous agricultural subsidies and push their case not only based on food security but on appeals to the role of farmers and the rural life in national culture. In fact, two achievements - though somewhat limited - of the Uruguay Round Agreements were the inclusion of agriculture and textiles into the GATT/WTO system (Jackson, 1997). The WTO Agriculture Agreement included provisions for improved market access and reduced trade-distorting subsidies, while the Agreement on Textiles and Clothing provided for the phase-out of the bilateral quotas that existed previously under the Multifibre Arrangement (MFA).

Table 6 gave one indication of the frequency with which the Triad members grant preference to less developed countries. These figures, however, do not shed any light on the depth of these preferences. Are they in sectors with already low tariffs or do they indeed grant a significant degree of preferential access? In Table 7 , we present two measures of the degree of preference and the change between 1993 and 2000. The first measure is the simple average of the difference between the MFN tariff and the GSPLDC tariffs across 10-digit HS commodities. The second measure is the simple average of the ratio of GSPLDC tariffs to MFN tariffs. In the 
Table 7. The extent of triad preferences for LDCs

\begin{tabular}{ccccccc}
\hline & \multicolumn{3}{c}{ Absolute Level of Preference* } & \multicolumn{3}{c}{ LDC Tariff as a Percent of MFN** } \\
\cline { 2 - 7 } & 1993 & 2000 & Change & 1993 & 2000 & Change \\
\hline United States & 2.55 & 1.95 & -0.59 & 54.3 & 51.2 & -3.0 \\
\hline European Union & 6.48 & 4.44 & -2.04 & 6.4 & 1.4 & -5.0 \\
\hline Japan & 9.54 & 3.07 & -6.47 & 43.8 & 29.8 & -14.1 \\
\hline
\end{tabular}

*This statistic is calculated as the simple average of the difference between 10-digit MFN tariffs and 10digit GSPLDC tariff.

**This statistic is calculated as 100 times the simple average of the GSPLDC tariff divided by each 10digit MFN tariff.

case of the United States in 1993, GSPLDC tariffs are those offered under the GSP program since there were no special rates for LDCs.

On average, the absolute level of preferences granted by each Triad member fell in the 1990s, as did the percentage difference between the LDC and MFN tariff. The United States had both the lowest decrease in the absolute level of preference and the smallest decline in the LDC tariff as a percent of the corresponding MFN tariff, with the EU in the middle on both and Japan the largest on both. The previous results of Table 5 shed light on these outcomes. Though the United States greatly increased its benefits to LDCs between 1993 and 2000, it also had the lowest MFN tariffs in both years, so the possible preference margin was limited in both periods. In addition, despite the increase in benefits, it was far less generous than the EU, which led all Triad members in LDC benefits both years. Japan's benefits were the worst in both years, but its MFN rates remained the highest though falling the most in absolute terms - suggesting that it retained a high possible preference margin.

As mentioned above, the Triad members have not granted preferences uniformly. Each member has a set of sensitive sectors, each of which has received less liberalization than have other sectors. The results presented in Table 7 are aggregate statistics that may mask changes at the sectoral level. Appendix D presents the statistics of Table 7 disaggregated by sector. An overwhelming finding in these tables is that the absolute level of preference has generally declined. In a period of significant tariff liberalization, this finding is not surprising. Only in the United States has it increased in several sectors, none of which could be identified as sensitive. Every 2-digit sector in the European Union and all but one sector in Japan saw an erosion of the absolute level of preference granted LDCs. LDC tariffs as a percentage of applied MFN tariffs have also 
fallen. Exceptions exist for the United States and Japan, but are almost exclusively in sensitive sectors - textiles and apparel in the United States and agriculture and food in Japan.

Preferences in policy give trading partners the opportunity to export to the Triad at preferential rates. However, there is no guarantee that the partner countries will be able to produce the goods eligible for preferences or fulfill the formalities required even if they can produce the eligible goods. Therefore, the next section investigates the extent to which the developing countries and LDCs actually benefit.

\section{Tariff Preferences in Practice}

The tariff rates and coverage explored in the previous section indicate that LDC preferences are granted fairly liberally across a wide range of sectors. While this is an important finding, it fails to provide an accurate picture of the effects of these preferences in practice. To provide such a picture and to clarify the implications of the preferences, this section incorporates trade patterns and focuses on importweighted average tariffs.

Triad imports from countries benefiting from GSPLDC preferences make up a startlingly small fraction of total Triad imports. Appendix E details the distribution of trade within country groups eligible for different preference schemes and across commodities. In all cases, the import numbers refer to all imports regardless of whether they receive preferences or not. On a percentage basis, the United States is the largest importer from LDCs, with 0.7 percent of all U.S. imports originating in these countries. The EU and Japan source a total of 0.4 and 0.3 percent of their imports from LDCs, respectively. Further, in the United States, in only the Textiles (4.5 percent) and Mineral Products (3.0 percent) sectors do LDC imports account for a significant proportion of total sector imports. In every other sector the LDC share of total imports is less than 1.1 percent. In the EU, only Textiles (4 percent) have significant LDC imports, while no sector in Japan sources more than 1.6 percent of imports from LDCs. Note that the total proportion of imports from LDCs may actually be much higher for the EU and slightly higher for the United States. For the EU, many ACP countries are LDCs, with 3.0 percent of EU imports coming from the ACP group. For the United States, Haiti, an LDC, is included in the Caribbean group. 
The tables in Appendix E for each Triad member are divided into two sections, and the second section gives the distribution of each Triad member's imports within country groups but across sectors. In all three Triad members, imports from LDCs are very highly concentrated. In the United States, Textiles and Mineral Products account for more than 90 percent of imports from LDCs. EU imports are even more highly concentrated with more than 83 percent accounted for by Textiles alone. Japanese imports from LDCs are only slightly more diversified, with 75 percent of these imports coming from Animals and Animal Products (43 percent), Vegetable Products (20 percent) and Mineral Products (14 percent).

Given this high concentration of Triad imports from LDCs, weighting tariffs imposed on these imports is likely to be important in understanding the effects of preferences in practice. Table 8 presents a brief time series of import-weighted average tariffs in the Triad. Reflecting the pattern of simple average tariffs shown in Table 5, there has been a significant decline in trade-weighted MFN tariffs, with Triad tariffs falling by almost 40 percent. Of more interest here than the time series changes in MFN tariffs is the relationship between the weighted average tariff applied to products from developed countries and those from LDCs. The preferences provided by the EU and Japan each have granted a large degree of special treatment to LDC exports. For the EU, the GSPLDC tariffs in particular have fallen to something negligible and LDCs are favored not only over most trade partners (as represented by the MFN tariff amount) but over other developing countries as well. The Japanese GSPLDC average tariffs are also less than half of those imposed on other countries, as represented by the MFN tariff rate, and somewhat lower than those imposed on exports from developing countries in general.

The United States, however, appears to have done a poor job of providing preferences to LDCs. Of the programs for developing countries, only the CBERA provides lower import-weighted average tariffs than does the MFN tariff schedule. The GSP tariffs have declined with the MFN tariffs, but remain somewhat higher. The GSPLDC tariffs and the ATPA tariffs are both more than double the MFN tariffs. This seems unlikely, as the GSPLDC and ATPA preference programs both take the GSP program as a starting point and expand its generosity. However, the products that play the largest role in LDC exports are those for which the United States retains the highest barriers for LDC and MFN countries alike.

As noted previously, U.S. imports from LDCs are concentrated by sector, with fully 40 percent in textiles and apparel. In Appendix F, we present import- 
Developed Country Trade Barriers and the Least Developed Countries: The Current Situation 247

Table 8. Import-weighted average tariffs

\begin{tabular}{ccccc}
\hline US & 1993 & 1996 & 2000 & Trade Share \\
\hline MFN & 4.49 & 3.13 & 2.33 & 54.2 \\
GSP & 5.52 & 3.18 & 2.74 & 11.2 \\
GSPLDC & -- & -- & 5.37 & 0.7 \\
CBERA & 1.90 & 1.58 & 1.68 & 1.9 \\
ATPA & 5.26 & 6.31 & 5.62 & 0.9 \\
Other ${ }^{13}$ & 0.45 & 0.26 & 0.05 & 31.2 \\
\hline EU & 1993 & 1996 & 2000 & Trade Share \\
\hline MFN & 4.40 & 4.10 & 2.91 & 54.6 \\
GSP & 1.99 & 3.49 & 2.40 & 29.6 \\
GSPLDC & 0.62 & 0.84 & 0.00 & 0.5 \\
ACP & 1.57 & 2.28 & 2.39 & 2.9 \\
Other & 0.57 & 0.41 & 0.26 & 12.5 \\
\hline Japan & 1993 & 1996 & 2000 & Trade Share \\
\hline MFN & 6.52 & 4.04 & 3.75 & 49.8 \\
GSP & 4.00 & 3.20 & 1.94 & 49.9 \\
GSPLDC & 2.23 & 2.52 & 1.80 & 0.3 \\
Other & -- & -- & -- & -- \\
\hline
\end{tabular}

weighted tariffs by sector. Clearly high tariffs on these products are responsible for the 5.4 percent tariffs on LDC imports reported in Table 8. Table F1 reports an 11.6 percent average tariff on LDC imports of Textiles and Textile Articles. Tariffs on Hides and Skins and Prepared Foodstuffs are also high, though exports of these commodities from LDCs constitute a very small share of total LDC exports to the United States.

In contrast, the EU and Japan impose very low tariffs on important export sectors for LDCs. The EU in particular imposes no tariffs on almost any LDC exports while Japan grants significant preferences on its major LDC import sectors. In particular, GSPLDC tariffs on Animals and Animal Products are 75 percent less than MFN tariffs. Tariffs on imports of Textiles and Textile Articles are less than 10 percent of their MFN counterpart. Tariffs on imports of Mineral Products from LDCs are somewhat higher than they are on imports from other countries, but are still very low at 0.61 percent.

Analyzing preferences in practice has so far proved productive. Most importantly,

\footnotetext{
${ }^{13}$ The "Other" row for each country reports the import-weighted average tariffs imposed on goods entering the Triad from partners that have other, generally reciprocal, trade arrangements, e.g., imports entering the United States under the North American Free Trade Agreement.
} 
while the United States grants generous preferences, partner countries appear unable to take advantage of them, in large part because the sectors most important to poor countries do not share in the overall generosity. In contrast, while Japan appears stingy in its preference policies, in practice it is less so since it grants preferences on many goods that the poorest countries are likely to export to it.

\section{The Geographic Impact of Triad Preferences for LDCs}

The analysis in the previous section highlights the disparity in tariff treatment given to different types of countries. As certain types of countries tend to be geographically close to one another this section explores the geographic incidence of LDC tariff preferences. ${ }^{14}$ Table 9 provides a comparison between the incidence of Triad tariffs on the trade of LDCs and non-LDC developing countries in the same region. This table highlights the results of the previous section in that the preference schemes of the EU are much more likely to provide significant benefits to LDC exports than are those of the United States. On a region-by-region basis, the preferences granted by the EU to LDCs are nearly always significantly lower than those granted to other developing countries. ${ }^{15}$ This is less true for Japan, and even less true for the United States, which in some cases heavily disfavors LDCs.

In the case of Japan, the preference programs afford lower average tariffs to LDC imports from Asian and Latin American countries. They exhibit higher average tariffs for trade with African and Middle Eastern LDCs than with nonLDC countries in these same regions, but the gap is nearly always less than one percentage point.

The United States, in contrast, though providing preferences that serve LDCs in Africa and the Middle East well, has enormously high effective tariffs against goods from LDCs in Asia and Latin America. Average tariffs in these regions are in excess of 10 percent on imports from LDC countries. These tariffs are in fact higher today than they were in 1993.

An analysis of these tariffs at the sectoral level helps explain the dramatic differences between, for example, U.S. tariffs on imports from Africa (1.31 percent) and Asia (10.95 percent). Appendix $\mathrm{H}$ provides a breakdown of both tariffs and import

\footnotetext{
${ }^{14}$ See Appendix $\mathrm{G}$ for a listing of countries and their LDC status by region. Both Latin America and the Middle East include only one LDC each, Haiti and Yemen, respectively.

${ }^{15}$ The only exception is the Middle East in 1996.
} 
Developed Country Trade Barriers and the Least Developed Countries: The Current Situation 249

Table 9. Geography and triad tariff preferences (Import-weighted average tariffs)

\begin{tabular}{ccccccc}
\hline \multirow{2}{*}{ US } & \multicolumn{2}{c}{1993} & \multicolumn{2}{c}{1996} & \multicolumn{2}{c}{2000} \\
\cline { 2 - 7 } & LDC & Non-LDC & LDC & Non-LDC & LDC & Non-LDC \\
\hline Africa & 3.44 & 4.05 & 1.61 & 1.24 & 1.31 & 2.95 \\
Asia & 10.73 & 4.83 & 11.20 & 3.45 & 10.95 & 2.59 \\
Latin America & 8.08 & 8.08 & 10.24 & 1.48 & 13.08 & 0.93 \\
Middle East & 2.28 & 4.75 & 1.27 & 1.97 & 0.00 & 2.00 \\
\hline & \multicolumn{2}{c}{1993} & \multicolumn{2}{c}{1996} & \multicolumn{2}{c}{2000} \\
\cline { 2 - 8 } EU & LDC & Non-LDC & LDC & Non-LDC & LDC & Non-LDC \\
\hline Africa & 0.03 & 2.44 & 0.47 & 1.56 & 0.37 & 1.37 \\
Asia & 0.68 & 3.91 & 0.83 & 5.49 & 0.00 & 3.30 \\
Latin America & -- & 3.36 & 0.00 & 3.72 & 0.01 & 2.92 \\
Middle East & 0.19 & 1.36 & 0.74 & 0.45 & 0.00 & 0.43 \\
\hline & \multicolumn{7}{c}{1993} & & 1996 & & 2000 \\
Japan & LDC & Non-LDC & LDC & Non-LDC & LDC & Non-LDC \\
\hline Africa & 1.79 & 2.44 & 2.14 & 2.21 & 1.75 & 1.45 \\
Asia & 2.27 & 5.15 & 1.72 & 3.55 & 1.37 & 2.69 \\
Latin America & 0.56 & 0.56 & 3.04 & 2.54 & 2.06 & 2.29 \\
Middle East & 1.07 & 2.03 & 3.14 & 2.21 & 1.35 & 0.22 \\
\hline
\end{tabular}

shares by commodity group. Some 86 percent of U.S. imports from Africa and the Middle East are in the Mineral Products sector, and therefore subject to very low levels of protection. Imports from LDCs in Asia and Latin America are largely Textiles and Textile Articles, goods subject to significant tariff barriers in the United States.

EU imports from LDCs are more diverse than are U.S. imports from these same countries. Imports from LDCs in Africa, for instance, are much less concentrated. Mineral Products make up 35 percent and are not subject to a tariff, and Precious Stones, Metals and Coins make up 15 percent and are also not subject to a tariff. Vegetable Products account for 14 percent and are subject to a low tariff, and Animals and Animal Products make up almost 11 percent. The last category is subject to a higher tariff than most other sectors and is largely responsible for the overall import-weighted tariff of 0.37 percent that African LDCs face when selling to the EU. Imports from the other three regions are somewhat more concentrated. Imports from Asia are 85 percent Textiles and Textile Articles, while 64 percent of imports from Latin American LDCs are Vegetable Products, neither of which are subject to tariffs. In addition, 64 percent of imports from the Middle East are 
Mineral Products, and subject to small tariffs on a few tariff lines in this category.

With the exception of imports from Middle Eastern LDCs, 92 percent of which are in the Mineral Products sector, Japanese imports from LDCs are also less concentrated than are U.S. imports. However, they still fall disproportionately in sectors that remain subject to tariff protection. Approximately 40 percent of imports from both Africa and Asia are in the heavily protected Animals and Animal Products sector. The high level of imports in this sector is perhaps the result of the significant preferences afforded LDC exports. Although Japanese imports of these products from LDCs are subject to an average tax of more than 4 percent, the MFN tariff is higher than 16 percent.

The sectoral patterns indicate again that average preferences cannot tell the full story. For a non-diversified economy or one incapable of producing a wide range of goods, the variance of preferences will be exceedingly important. They can result in the overall trade tax rate incurred by LDCs being higher than that incurred by the advanced industrial countries, which can focus their production on low-tariff items. Furthermore, because regions tend to specialize, an imbalance among preferences can leave groups of LDCs in a less-favored trade position.

\section{LDC Tariff Policies}

Although the issue for the Doha Round of negotiations is providing preferential access to all developed markets from LDCs, this result is unlikely to come about unless LDCs agree to reductions of barriers to market access in their own countries. As such, this section provides a snapshot of tariff barriers as applied in LDCs. On the whole, LDC barriers to imports are very high. The average tariffs in these countries, both simple and import-weighted, are generally in the teens with a handful of simple average tariffs entering the 20s. In only three countries, Madagascar, Mali, and the Sudan, are simple average tariffs in the single digits.

The bottom of Table 10 presents aggregates of these tariff measures across LDCs and examines the extent to which they apply to countries of different income levels. The LDCs show a slight bias in favor of the richest nations in their trade policy. Import-weighted average tariffs as applied to High Income countries are high, but significantly lower than those applied to countries with relatively low incomes. Despite many regional agreements among Low Income countries, barriers imposed against other Low Income countries remain high. These agreements include the South Asian Association for Regional Cooperation 
Developed Country Trade Barriers and the Least Developed Countries: The Current Situation 251

Table 10. Tariffs imposed by LDCs ${ }^{16}$

\begin{tabular}{|c|c|c|c|c|c|c|}
\hline \multirow{3}{*}{ Importer } & \multicolumn{2}{|c|}{ Tariffs } & \multirow{3}{*}{$\begin{array}{c}\text { Imports } \\
\text { Thousands } \\
\text { of US \$ }\end{array}$} & \multirow{2}{*}{\multicolumn{3}{|c|}{$\begin{array}{l}\text { Import-weighted Average Tariffs } \\
\text { on Goods from Triad Members }\end{array}$}} \\
\hline & \multirow{2}{*}{$\begin{array}{l}\text { Simple } \\
\text { Average }\end{array}$} & \multirow{2}{*}{$\begin{array}{c}\text { Import } \\
\text { Weighted }\end{array}$} & & & & \\
\hline & & & & US & EU & JP \\
\hline Bangladesh & 21.5 & 21.6 & $5,863,529$ & 7.7 & 14.6 & 14.1 \\
\hline Benin & 14.6 & 12.8 & 806,977 & 13.7 & 13.7 & 15.1 \\
\hline Bhutan & 15.3 & 15.5 & 85,539 & 10.7 & 12.6 & 21.1 \\
\hline Burkina Faso & 12.5 & 10.0 & 170,769 & 12.5 & 9.9 & . \\
\hline Central African Republic & 18.4 & 15.9 & 52,066 & 12.6 & 16.1 & . \\
\hline Chad & 16.7 & 12.7 & 262,506 & 11.4 & 14.1 & . \\
\hline Equatorial Guinea & 17.2 & 13.6 & 115,579 & 11.1 & 19.2 & . \\
\hline Ethiopia & 16.3 & 10.9 & 153,009 & 10.1 & 10.7 & . \\
\hline Guinea-Bissau & 12.7 & 14.3 & 6,930 & 9.8 & 14.7 & . \\
\hline Madagascar & 6.9 & 5.1 & 501,291 & 5.5 & 5.5 & 10.0 \\
\hline Malawi & 11.2 & 8.2 & 24,282 & 11.2 & 5.7 & . \\
\hline Maldives & 21.2 & 19.0 & 388,585 & 23.2 & 22.2 & 30.9 \\
\hline Mali & 12.6 & 9.4 & 286,727 & 8.2 & 9.5 & . \\
\hline Mauritania & 11.5 & 9.1 & 261,111 & 10.1 & 8.9 & . \\
\hline Mozambique & 12.9 & 13.8 & 83,900 & 15.7 & 11.5 & . \\
\hline Nepal & 14.1 & 16.5 & $1,340,953$ & 9.5 & 13.9 & 43.6 \\
\hline Niger & 14.2 & 12.5 & 419,981 & 12.7 & 11.8 & 14.6 \\
\hline Rwanda & 9.4 & 8.1 & 49,231 & 8.5 & 7.8 & . \\
\hline Senegal & 13.8 & 8.4 & $1,552,794$ & 7.7 & 10.2 & 12.8 \\
\hline Sudan & 5.1 & 3.6 & $1,041,836$ & 2.1 & 3.8 & 3.0 \\
\hline Tanzania & 16.3 & 14.1 & $1,544,885$ & 13.7 & 14.0 & 10.3 \\
\hline Uganda & 9.0 & 7.4 & 935,631 & 6.2 & 5.5 & 9.9 \\
\hline Zambia & 14.1 & 10.5 & 646,211 & 11.3 & 10.8 & 14.4 \\
\hline TOTAL & 16.0 & 14.7 & $16,594,323$ & 9.5 & 11.1 & 14.1 \\
\hline \multicolumn{7}{|l|}{ Exporter Group } \\
\hline High Income & 15.3 & 13.6 & $18,236,787$ & & & \\
\hline Upper Middle Income & 14.8 & 12.4 & $4,796,018$ & & & \\
\hline Lower Middle Income & 18.3 & 17.4 & $4,421,340$ & & & \\
\hline Low Income & 17.5 & 18.3 & $5,650,223$ & & & \\
\hline
\end{tabular}

(SAARC), the Customs and Economic Union of Central Africa (UDEAC), and the Common Market for Eastern and Southern Africa (COMESA). The LDCs participating in one or more of these arrangements are: Bangladesh (SAARC), Central African Republic (UDEAC), Chad (UDEAC), Malawi (COMESA), and

${ }^{16}$ This set of countries is only a subset of the LDCs listed in Appendix A. No data are available for the remaining LDCs. 


\section{Sudan (COMESA) ${ }^{17}$.}

Among the three Triad members, the United States faces the lowest tradeweighted tariffs on its exports to LDCs, as shown in the last three columns of Table 10. This is ironic as U.S. trade-weighted tariffs on LDC goods are the highest of the Triad members. A reason for low tariffs on U.S. goods may include the composition, with LDCs importing those goods that have the lowest tariffs or instituting low tariffs on goods they most need. An alternate but not mutually exclusive reason may be that many of the imports are components used in productionsharing arrangements and therefore by policy face low tariffs. The EU faces an intermediate level of tariffs on its exports to the LDCs, while Japan faces the highest trade-weighted tariffs. Tariffs on Japanese products show the most variation as well, ranging from 3.0 percent in Sudan to 43.6 percent in Nepal.

\section{Conclusion}

Preferential trading arrangements for developing countries are not a new phenomenon. These preferences have traditionally been significantly less than comprehensive, however. To the extent that the developed nations collectively can agree to eliminate the remaining barriers to LDC imports, we expect to witness a significant increase in the flow of exports from LDCs to the developed nations.

This paper documents the extent to which there is further preferential liberalization to be done, but does not attempt to quantify the expansion of LDC exports that is likely to arise from such liberalization. In policy, the three economies of the Triad the United States, the European Union, and Japan offer significant tariff preferences for imports from developing countries over imports from nations subject to MFN tariffs. However, the impact of the preferences in practice is mixed. The European Union, the economy implementing the most significant set of preferences, offers the best terms for goods that developing nations are able to export. Japan also offers preferences that the least developed countries use. The United States, in contrast, still maintains high tariffs on many of the products that developing economies are most able to export.

These mixed results indicate that careful attention to the implementation of the Doha goal-quota-free, duty-free market access for LDC products will be necessary.

\footnotetext{
${ }^{17}$ Bangladesh is also a party to the Bangkok Agreement, providing preferences to India, Sri Lanka and South Korea. In addition to its participation in COMESA, Malawi provides preferences to Zimbabwe.
} 
First, any such agreement should ensure coverage of the products that LDCs are most likely to export. This is especially important if improved market access takes place in stages, as many trade reforms do. Second, the results imply that any such reform should prohibit bureaucratic obstacles, such as complex rules of origin, that could negate liberalization policies. The results indicate that there is, in fact, still much room for tariff reductions in the world's leading economy, that of the United States. Finally, insofar as trade liberalization can lead to development, the results indicate that there is still great potential to improve the prospects of the least developed countries.

\section{Acknowledgments}

The authors thank Basudeb Guha-Khasnobis, project director of the United Nations University-World Institute for Development Economics Research project on The Impact of the WTO Agreement on Low Income Countries, and participants at the project meeting in Helsinki in October 2002 for comments; Eli Miloslavsky for excellent research assistance; and Paul King for helpful library assistance.

Recevied 7 August 2003, Accepted 27 January 2004

\section{References}

Cernat, Lucian, Sam Laird, Luca Monge-Roffarello, and Alessandro Turrini(2004). "The EU's Everything But Arms Initiative and the Least-developed Countries," in The WTO, Developing Countries and the Doha Development Agenda: Prospects and Challenges for Trade-Led Growth, (Ed.) Basudeb Guha-Khasnobis, Palgrave Macmillan, Houndmills, Basingstoke, Hampshire, England.

European Union (1999). "Vademecum: Guide to the European Union's Scheme of Generalised Tariff Preferences." Web Document. Available at http://europea.eu.int/ comm/trade/pdf/guide_tariffpref.pdf.

European Union (2002). "User's Guide to the European Union's Scheme of Generalised Tariff Preferences." (April). Web Document. Available at http://europea.eu.int/ comm/trade/miti/devel/gspguide.htm.

Haveman, Jon D., and Howard J. Shatz (2004). "Developed Country Trade Barriers and the Least Developed Countries: The Economic Results of Freeing Trade." in The WTO, Developing Countries and the Doha Development Agenda: Prospects and Challenges for Trade-Led Growth, (Ed.) Basudeb Guha-Khasnobis, Palgrave Macmillan, Houndmills, Basingstoke, Hampshire, England. 
Jackson, John H. (1997). The World Trading System: Law and Policy of International Economic Relations. Cambridge, Mass., and London: The MIT Press.

Ministry of Economics, Trade, and Industry (2000). "Policy Information: 99\% Initiative on Industrial Tariffs for products from Least Developed Countries (LDCs)." Web Document. Available at http://www.meti.go.jp/english/information/data/cLDC01e.html (13 December).

Ministry of Foreign Affairs (undated). Japan and the Least Developed Countries: Beyond One Dollar A Day. Tokyo: MOFA.

Office of the United States Trade Representative (1999). Third Report to the Congress on the Operation of the Caribbean Basin Economic Recovery Act, October 1, 1999. Washington, D.C.: USTR.

World Trade Organization (2001). "Ministerial Declaration," November 20, WT/MIN(01)/ DEC/1. 
Developed Country Trade Barriers and the Least Developed Countries: The Current Situation 255

\section{Appendix A}

The Least Developed Countries

\begin{tabular}{ll}
\hline Afghanistan & Madagascar \\
Angola & Malawi \\
Bangladesh & Maldives \\
Benin & Mali \\
Bhutan & Mauritania \\
Burkina Faso & Mozambique \\
Burundi & Myanmar \\
Cambodia & Nepal \\
Cape Verde & Niger \\
Central African Republic & Rwanda \\
Chad & Samoa \\
Comoros & Sao Tome and Principe \\
Democratic Republic of Congo & Senegal \\
Djibouti & Sierra Leone \\
Equatorial Guinea & Solomon Islands \\
Eritrea & Somalia \\
Ethiopia & Sudan \\
Gambia & Togo \\
Guinea & Tuvalu \\
Guinea Bissau & Uganda \\
Haiti & United Republic of Tanzania \\
Kiribati & Vanuatu \\
Lao Peoples Democratic Republic & Yemen \\
Lesotho & Zambia \\
Liberia & \\
\hline
\end{tabular}

Source: United Nations Conference on Trade and Development. 


\section{Appendix B}

Simple Average Tariff Barriers by Preference Program Country Group

Table B1. United States

\begin{tabular}{lrrrrrr}
\hline & MFN & GSP & GSPLDC & ANDEAN & CBERA & ACP \\
\hline Animal or Veg. Fats, Oils \& Waxes & 2.55 & 1.61 & 0.00 & 0.00 & 0.00 &. \\
Animals \& Animal Products & 1.90 & 1.57 & 0.37 & 0.37 & 0.37 &. \\
Arms \& Ammunition & 1.13 & 0.05 & 0.00 & 0.00 & 0.00 &. \\
Articles of Stone, Plaster, Cement & 3.63 & 1.38 & 0.40 & 0.12 & 0.12 &. \\
Base metals \& Articles thereof & 2.54 & 0.92 & 0.01 & 0.00 & 0.00 &. \\
Chemical Products & 3.11 & 0.89 & 0.00 & 0.00 & 0.00 &. \\
Footwear, Headgear & 6.99 & 5.40 & 5.40 & 5.12 & 5.08 &. \\
Hides \& Skins & 2.96 & 1.70 & 1.32 & 0.97 & 0.97 &. \\
Instruments & 1.90 & 0.31 & 0.13 & 0.00 & 0.00 &. \\
Machinery \& Mechanical Appliances & 1.41 & 0.16 & 0.00 & 0.00 & 0.00 &. \\
Mineral Products & 0.21 & 0.06 & 0.00 & 0.00 & 0.00 &. \\
Miscellaneous Manufactured Articles & 2.85 & 0.32 & 0.06 & 0.02 & 0.01 &. \\
Plastics \& Rubber & 3.66 & 0.27 & 0.06 & 0.04 & 0.01 &. \\
Precious Stones, Metals, Coins & 2.16 & 0.09 & 0.00 & 0.00 & 0.00 &. \\
Prepared Foodstuffs & 15.49 & 13.26 & 11.10 & 11.15 & 11.15 &. \\
Special Classification Provisions & 9.62 & 9.45 & 9.45 & 8.92 & 8.15 &. \\
Textiles \& Textile Articles & 3.30 & 1.57 & 0.00 & 0.00 & 0.00 &. \\
Transportation Equipment & 3.92 & 2.68 & 1.36 & 1.17 & 1.17 &. \\
Vegetable Products & 1.16 & 0.18 & 0.06 & 0.05 & 0.05 &. \\
Wood \& Wood Products & 0.71 & 0.00 & 0.00 & 0.00 & 0.00 &. \\
Wood Pulp \& Products & 0.00 & 0.00 & 0.00 & 0.00 & 0.00 &. \\
Works of Art, Collector's Pieces \& Antiq & 2.55 & 1.61 & 0.00 & 0.00 & 0.00 &. \\
\hline
\end{tabular}

Table B2. European Union

\begin{tabular}{lcccccc}
\hline & MFN & GSP & GSPLDC ANDEAN CBERA & ACP \\
\hline Animal or Veg. Fats, Oils \& Waxes & 4.79 & 3.08 & 0.00 &. &. & 0.09 \\
Animals \& Animal Products & 7.24 & 5.66 & 0.21 &. &. & 0.11 \\
Arms \& Ammunition & 2.37 & 2.37 & 2.37 &. &. & 0.00 \\
Articles of Stone, Plaster, Cement & 3.41 & 1.23 & 0.00 &. &. & 0.00 \\
Base metals \& Articles thereof & 2.85 & 0.95 & 0.00 &. &. & 0.00 \\
Chemical Products & 4.68 & 1.15 & 0.00 &. &. & 0.00 \\
Footwear, Headgear & 7.59 & 4.49 & 0.00 &. &. & 0.00 \\
Hides \& Skins & 2.53 & 1.28 & 0.00 &. &. & 0.00 \\
Instruments & 2.30 & 0.63 & 0.00 &. &. & 0.00 \\
Machinery \& Mechanical Appliances & 2.06 & 0.42 & 0.00 &. &. & 0.00 \\
Mineral Products & 0.22 & 0.00 & 0.00 &. &. & 0.00 \\
\hline
\end{tabular}


Developed Country Trade Barriers and the Least Developed Countries: The Current Situation 257

Table B2. Continued

\begin{tabular}{lrrrrrr}
\hline & MFN & GSP & GSPLDC ANDEAN CBERA & ACP \\
\hline Miscellaneous Manufactured Articles & 2.83 & 0.64 & 0.00 &. &. & 0.00 \\
Plastics \& Rubber & 5.46 & 1.24 & 0.00 &. &. & 0.00 \\
Precious Stones, Metals, Coins & 0.59 & 0.05 & 0.00 &. &. & 0.00 \\
Prepared Foodstuffs & 12.12 & 8.98 & 0.85 &. &. & 0.72 \\
Special Classification Provisions & 8.67 & 7.32 & 0.00 &. &. & 0.00 \\
Textiles \& Textile Articles & 3.98 & 1.90 & 0.00 &. &. & 0.00 \\
Transportation Equipment & 5.33 & 4.09 & 0.58 &. &. & 1.00 \\
Vegetable Products & 2.88 & 1.55 & 0.00 &. &. & 0.00 \\
Wood \& Wood Products & 2.90 & 0.13 & 0.00 &. &. & 0.00 \\
Wood Pulp \& Products & 0.00 & 0.00 & 0.00 &. &. & 0.00 \\
Works of Art, Collector's Pieces \& Antiq & 4.79 & 3.08 & 0.00 &. &. & 0.09 \\
\hline
\end{tabular}

Table B3. Japan

\begin{tabular}{lrrrrcc}
\hline & MFN & GSP & GSPLDC ANDEAN CBERA & ACP \\
\hline Animal or Veg. Fats, Oils \& Waxes & 5.93 & 4.69 & 4.60 &. &. &. \\
Animals \& Animal Products & 8.95 & 8.80 & 8.71 &. &. &. \\
Arms \& Ammunition & 9.24 & 0.06 & 0.00 &. &. &. \\
Articles of Stone, Plaster, Cement & 1.37 & 0.00 & 0.00 &. &. &. \\
Base metals \& Articles thereof & 3.10 & 0.01 & 0.00 &. &. &. \\
Chemical Products & 3.38 & 0.02 & 0.01 &. &. &. \\
Footwear, Headgear & 16.84 & 7.53 & 4.15 &. &. &. \\
Hides \& Skins & 10.99 & 4.14 & 2.51 &. &. &. \\
Instruments & 0.13 & 0.04 & 0.04 &. &. &. \\
Machinery \& Mechanical Appliances & 0.10 & 0.00 & 0.00 &. &. &. \\
Mineral Products & 0.57 & 0.15 & 0.15 &. &. &. \\
Miscellaneous Manufactured Articles & 2.49 & 0.07 & 0.00 &. &. &. \\
Plastics \& Rubber & 3.70 & 0.00 & 0.00 &. &. &. \\
Precious Stones, Metals, Coins & 1.09 & 0.00 & 0.00 &. &. &. \\
Prepared Foodstuffs & 15.49 & 13.95 & 11.47 &. &. &. \\
Special Classification Provisions & 8.45 & 2.96 & 0.75 &. &. &. \\
Textiles \& Textile Articles & 0.23 & 0.00 & 0.00 &. &. &. \\
Transportation Equipment & 6.91 & 5.87 & 5.38 &. &. &. \\
Vegetable Products & 5.75 & 0.98 & 0.86 &. &. &. \\
Wood \& Wood Products & 2.12 & 0.00 & 0.00 &. &. &. \\
Wood Pulp \& Products & 0.00 & 0.00 & 0.00 &. &. &. \\
Works of Art, Collector's Pieces \& Antiq & 5.93 & 4.69 & 4.60 &. &. &. \\
\hline
\end{tabular}




\section{Appendix C}

Industrial Distribution of All Triad Preferences for Developing Countries, 2000

\begin{tabular}{lccc}
\hline & \multicolumn{3}{c}{$\begin{array}{c}\text { Proportion of HS Codes } \\
\text { With a Preference }\end{array}$} \\
\cline { 2 - 4 } & US & EU & Japan \\
\hline Animal or Veg. Fats, Oils \& Waxes & 0.52 & 0.81 & 0.28 \\
Animals \& Animal Products & 0.45 & 0.73 & 0.06 \\
Arms \& Ammunition & 0.40 & 0.93 & 1.00 \\
Articles of Stone, Plaster, Cement & 0.62 & 0.86 & 0.38 \\
Base metals \& Articles thereof & 0.80 & 0.89 & 0.67 \\
Chemical Products & 0.68 & 0.76 & 0.70 \\
Footwear, Headgear & 0.26 & 0.98 & 0.75 \\
Hides \& Skins & 0.72 & 0.67 & 0.57 \\
Instruments & 0.56 & 0.69 & 0.02 \\
Machinery \& Mechanical Appliances & 0.46 & 0.72 & 0.02 \\
Mineral Products & 0.06 & 0.21 & 0.11 \\
Miscellaneous & 0.50 & 0.84 & 0.57 \\
Plastics \& Rubber & 0.77 & 0.81 & 0.75 \\
Precious Stones, Metals, Coins & 0.53 & 0.23 & 0.26 \\
Prepared Foodstuffs & 0.64 & 0.80 & 0.31 \\
Textiles \& Textile Articles & 0.30 & 0.96 & 0.81 \\
Transportation Equipment & 0.51 & 0.88 & 0.01 \\
Vegetable Products & 0.46 & 0.61 & 0.21 \\
Wood \& Wood Products & 0.40 & 0.57 & 0.52 \\
Wood Pulp \& Products & 0.56 & 0.76 & 0.59 \\
Works of Art, Collector's Pieces \& Antiq & 0.00 & 0.00 & 0.00 \\
\hline
\end{tabular}

\section{Appendix D}

The Extent of Triad Preferences for LDCs

Table D1. United States

\begin{tabular}{lrrrrrr}
\hline & \multicolumn{3}{c}{$\begin{array}{c}\text { Absolute Level of } \\
\text { Preference* }\end{array}$} & \multicolumn{3}{c}{$\begin{array}{c}\text { LDC Tariff as a Percent } \\
\text { of MFN** }\end{array}$} \\
\cline { 2 - 7 } & 1993 & 2000 & Change & 1993 & 2000 & Change \\
\hline Animal or Veg. Fats, Oils \& Waxes & 1.65 & 3.09 & 1.44 & 62.8 & 0.0 & -62.8 \\
Animals \& Animal Products & 0.71 & 1.87 & 1.16 & 70.1 & 21.8 & -48.4 \\
Arms \& Ammunition & 3.96 & 1.06 & -2.90 & 3.4 & 0.0 & -3.4 \\
Articles of Stone, Plaster, Cement & 4.20 & 3.10 & -1.10 & 31.2 & 13.5 & -17.7 \\
\hline
\end{tabular}


Developed Country Trade Barriers and the Least Developed Countries: The Current Situation 259

Table D1. Continued

\begin{tabular}{lrrrrrr}
\hline Base metals \& Articles thereof & 2.39 & 2.42 & 0.03 & 47.7 & 0.4 & -47.3 \\
Chemical Products & 3.35 & 3.15 & -0.21 & 30.7 & 0.0 & -30.7 \\
Footwear, Headgear & 2.93 & 1.57 & -1.36 & 73.5 & 80.6 & 7.1 \\
Hides \& Skins & 2.05 & 1.64 & -0.41 & 55.2 & 48.9 & -6.3 \\
Instruments & 4.90 & 1.88 & -3.02 & 11.7 & 8.9 & -2.9 \\
Machinery \& Mechanical Appliances & 3.33 & 1.43 & -1.90 & 9.7 & 0.0 & -9.7 \\
Mineral Products & 0.60 & 0.18 & -0.42 & 24.7 & 0.0 & -24.7 \\
Miscellaneous Manufactured Articles & 4.87 & 2.56 & -2.31 & 15.5 & 3.4 & -12.2 \\
Plastics \& Rubber & 3.71 & 3.60 & -0.11 & 9.4 & 0.8 & -8.6 \\
Precious Stones, Metals, Coins & 3.99 & 2.15 & -1.85 & 6.8 & 0.0 & -6.8 \\
Prepared Foodstuffs & 3.62 & 4.47 & 0.85 & 46.9 & 68.4 & 21.5 \\
Textiles \& Textile Articles & 0.28 & 0.17 & -0.11 & 97.6 & 98.2 & 0.6 \\
Transportation Equipment & 3.01 & 3.09 & 0.08 & 26.5 & 0.0 & -26.5 \\
Vegetable Products & 1.99 & 2.72 & 0.73 & 55.4 & 40.8 & -14.6 \\
Wood \& Wood Products & 2.30 & 1.34 & -0.96 & 12.0 & 1.9 & -10.2 \\
Wood Pulp \& Products & 1.91 & 0.75 & -1.16 & 0.0 & 0.0 & 0.0 \\
Works of Art, Collector's Pieces \& Antiq & 0.00 & 0.00 & 0.00 &. &. &. \\
All Industries & 2.55 & 1.95 & -0.59 & 54.3 & 51.2 & -3.0 \\
\hline
\end{tabular}

*This statistic is calculated as the simple average of the difference between 10-digit MFN tariffs and 10digit GSPLDC tariff.

**This statistic is calculated as the 100 times the simple average of the GSPLDC tariff divided by each 10-digit MFN tariff.

Table D2. European Union

\begin{tabular}{lrrrrrr}
\hline & \multicolumn{3}{c}{$\begin{array}{c}\text { Absolute Level of } \\
\text { Preference* }\end{array}$} & \multicolumn{3}{c}{$\begin{array}{c}\text { LDC Tariff as a Percent } \\
\text { of MFN** }\end{array}$} \\
\cline { 2 - 7 } & 1993 & 2000 & Change & 1993 & 2000 & Change \\
\hline Animal or Veg. Fats, Oils \& Waxes & 6.45 & 5.19 & -1.26 & 7.5 & 0.0 & -7.5 \\
Animals \& Animal Products & 7.51 & 6.46 & -1.04 & 21.6 & 3.4 & -18.1 \\
Arms \& Ammunition & 4.65 & 0.00 & -4.65 & 5.0 & 100.0 & 95.0 \\
Articles of Stone, Plaster, Cement & 5.61 & 3.58 & -2.03 & 1.1 & 0.0 & -1.1 \\
Base metals \& Articles thereof & 4.79 & 2.80 & -1.99 & 7.2 & 0.0 & -7.2 \\
Chemical Products & 6.83 & 4.63 & -2.20 & 3.8 & 0.0 & -3.8 \\
Footwear, Headgear & 9.35 & 7.27 & -2.08 & 0.0 & 0.0 & 0.0 \\
Hides \& Skins & 3.24 & 2.33 & -0.90 & 7.2 & 0.0 & -7.2 \\
Instruments & 5.54 & 2.43 & -3.11 & 1.3 & 0.0 & -1.3 \\
Machinery \& Mechanical Appliances & 4.62 & 1.98 & -2.65 & 1.5 & 0.0 & -1.5 \\
Mineral Products & 0.52 & 0.22 & -0.30 & 19.0 & 0.0 & -19.0 \\
Miscellaneous Manufactured Articles & 6.15 & 2.82 & -3.33 & 1.5 & 0.0 & -1.5 \\
Plastics \& Rubber & 7.31 & 5.20 & -2.12 & 2.5 & 0.0 & -2.5 \\
Precious Stones, Metals, Coins & 1.91 & 0.61 & -1.30 & 2.7 & 0.0 & -2.7 \\
\hline
\end{tabular}


Table D2. Continued

\begin{tabular}{lrrrrrr}
\hline Prepared Foodstuffs & 14.20 & 11.83 & -2.37 & 27.3 & 5.3 & -21.9 \\
Textiles \& Textile Articles & 10.07 & 8.63 & -1.43 & 0.7 & 0.0 & -0.7 \\
Transportation Equipment & 5.95 & 3.99 & -1.96 & 5.8 & 0.0 & -5.8 \\
Vegetable Products & 5.34 & 4.45 & -0.89 & 27.5 & 12.3 & -15.1 \\
Wood \& Wood Products & 4.57 & 2.73 & -1.84 & 8.2 & 0.0 & -8.2 \\
Wood Pulp \& Products & 7.09 & 2.78 & -4.30 & 2.2 & 0.0 & -2.2 \\
Works of Art, Collector's Pieces \& Antiq & 0.00 & 0.00 & 0.00 & \multicolumn{1}{c}{.} &. &. \\
All Industries & 6.48 & 4.44 & -2.04 & 6.4 & 1.4 & -5.0 \\
\hline
\end{tabular}

*This statistic is calculated as the simple average of the difference between 10-digit MFN tariffs and 10digit GSPLDC tariff.

**This statistic is calculated as the 100 times the simple average of the GSPLDC tariff divided by each 10-digit MFN tariff.

Table D3. Japan

\begin{tabular}{|c|c|c|c|c|c|c|}
\hline & \multicolumn{3}{|c|}{$\begin{array}{l}\text { Absolute Level of } \\
\text { Preference* }\end{array}$} & \multicolumn{3}{|c|}{$\begin{array}{l}\text { LDC Tariff as a Percent of } \\
\text { MFN** }\end{array}$} \\
\hline & 1993 & 2000 & Change & 1993 & 2000 & Change \\
\hline Animal or Veg. Fats, Oils \& Waxes & 5.94 & 1.56 & -4.38 & 50.2 & 75.2 & 25.1 \\
\hline Animals \& Animal Products & 0.39 & 0.27 & -0.12 & 97.2 & 97.2 & 0.0 \\
\hline Arms \& Ammunition & 20.59 & 9.08 & -11.50 & 0.0 & 0.0 & 0.0 \\
\hline Articles of Stone, Plaster, Cement & 6.72 & 1.65 & -5.07 & 56.9 & 0.0 & -56.9 \\
\hline Base metals \& Articles thereof & 10.67 & 2.95 & -7.71 & 32.3 & 0.1 & -32.2 \\
\hline Chemical Products & 15.09 & 3.44 & -11.65 & 14.3 & 0.4 & -14.0 \\
\hline Footwear, Headgear & 16.45 & 13.05 & -3.40 & 28.0 & 26.2 & -1.8 \\
\hline Hides \& Skins & 11.53 & 9.66 & -1.87 & 30.9 & 21.7 & -9.2 \\
\hline Instruments & 0.84 & 0.13 & -0.70 & 96.0 & 29.2 & -66.9 \\
\hline Machinery \& Mechanical Appliances & 0.29 & 0.07 & -0.21 & 98.2 & 0.0 & -98.2 \\
\hline Mineral Products & 1.11 & 0.27 & -0.84 & 60.7 & 28.4 & -32.4 \\
\hline Miscellaneous Manufactured Articles & 11.68 & 2.58 & -9.09 & 42.6 & 0.0 & -42.6 \\
\hline Plastics \& Rubber & 17.49 & 3.58 & -13.91 & 10.5 & 0.0 & -10.5 \\
\hline Precious Stones, Metals, Coins & 7.47 & 1.19 & -6.28 & 32.4 & 0.0 & -32.4 \\
\hline Prepared Foodstuffs & 7.86 & 3.78 & -4.08 & 66.9 & 74.8 & 7.9 \\
\hline Textiles \& Textile Articles & 20.05 & 7.65 & -12.40 & 7.7 & 9.3 & 1.5 \\
\hline Transportation Equipment & 0.00 & 0.10 & 0.10 & 100.0 & 0.0 & -100.0 \\
\hline Vegetable Products & 3.15 & 1.46 & -1.68 & 75.9 & 80.1 & 4.2 \\
\hline Wood \& Wood Products & 9.71 & 4.01 & -5.70 & 11.8 & 10.3 & -1.6 \\
\hline Wood Pulp \& Products & 10.54 & 2.22 & -8.32 & 12.5 & 0.0 & -12.5 \\
\hline Works of Art, Collector's Pieces \& Antiq & 0.00 & 0.00 & 0.00 & 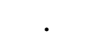 & . & . \\
\hline All Industries & 9.54 & 3.07 & -6.47 & 43.9 & 29.8 & -14.1 \\
\hline
\end{tabular}

*This statistic is calculated as the simple average of the difference between 10-digit MFN tariffs and 10digit GSPLDC tariff.

**This statistic is calculated as the 100 times the simple average of the GSPLDC tariff divided by each 10-digit MFN tariff. 
Developed Country Trade Barriers and the Least Developed Countries: The Current Situation 261

\section{Appendix E}

Trade Shares Within Sector, by Preference Scheme Country Group, 2000

\begin{tabular}{lrrrrrrr}
\hline \multicolumn{1}{c}{ United States } & MFN & GSP & GSPLDC & CBERA & ATPA & ACP & Other \\
\hline Animal or Veg. Fats, Oils \& Waxes & 47.6 & 28.0 & 0.1 & 0.1 & 0.6 &. & 23.6 \\
Animals \& Animal Products & 32.9 & 22.1 & 1.1 & 4.7 & 2.4 &. & 36.8 \\
Arms \& Ammunition & 71.5 & 14.0 & 0.0 & 0.0 & 0.1 &. & 14.4 \\
Articles of Stone, Plaster, Cement & 61.2 & 11.5 & 0.0 & 1.6 & 0.5 &. & 25.1 \\
Base metals \& Articles thereof & 45.9 & 17.9 & 0.1 & 0.5 & 1.6 &. & 34.1 \\
Chemical Products & 74.3 & 8.6 & 0.0 & 1.5 & 1.1 &. & 14.5 \\
Footwear, Headgear & 78.7 & 15.6 & 1.0 & 1.5 & 0.0 &. & 3.2 \\
Hides \& Skins & 66.9 & 24.2 & 0.3 & 1.0 & 0.5 &. & 7.0 \\
Instruments & 74.9 & 3.3 & 0.0 & 1.4 & 0.0 &. & 20.4 \\
Machinery \& Mechanical Appliances & 67.4 & 7.0 & 0.0 & 0.5 & 0.0 &. & 25.2 \\
Mineral Products & 29.6 & 25.0 & 3.1 & 2.6 & 3.8 &. & 35.9 \\
Miscellaneous & 69.7 & 6.3 & 0.0 & 0.3 & 0.1 &. & 23.5 \\
Plastics \& Rubber & 52.5 & 8.6 & 0.0 & 0.7 & 0.2 &. & 37.9 \\
Precious Stones, Metals, Coins & 34.0 & 32.5 & 0.2 & 0.9 & 1.6 &. & 30.8 \\
Prepared Foodstuffs & 42.9 & 19.7 & 0.4 & 4.3 & 1.4 &. & 31.4 \\
Special Classification Provisions & 48.3 & 5.2 & 0.1 & 1.4 & 1.0 &. & 43.9 \\
Textiles \& Textile Articles & 38.4 & 23.3 & 4.5 & 13.0 & 1.2 &. & 19.5 \\
Transportation Equipment & 50.3 & 1.9 & 0.0 & 0.0 & 0.0 &. & 47.8 \\
Vegetable Products & 15.3 & 21.9 & 1.0 & 14.2 & 11.8 &. & 36.0 \\
Wood \& Wood Products & 16.0 & 12.6 & 0.0 & 0.5 & 0.7 &. & 70.2 \\
Wood Pulp \& Products & 29.0 & 4.7 & 0.0 & 0.1 & 0.2 &. & 66.0 \\
Works of Art, Collector's Pieces \& Antiq & 91.4 & 4.6 & 0.2 & 0.2 & 0.2 &. & 3.4 \\
\hline \multicolumn{1}{c}{ Total } & 54.1 & 11.1 & 0.7 & 1.8 & 0.9 &. & 31.4 \\
\hline & & & & & &
\end{tabular}

Within Preference Scheme Country Group Trade Shares by Sector, 2000

\begin{tabular}{lrrrrrrrr}
\hline \multicolumn{1}{c}{ United States } & MFN & GSP & GSPLDC & CBERA & ATPA & ACP & Other \\
\hline Animal or Veg. Fats, Oils \& Waxes & 0.10 & 0.29 & 0.01 & 0.01 & 0.07 &. & 0.09 \\
Animals \& Animal Products & 0.76 & 2.45 & 2.00 & 3.11 & 3.20 &. & 1.46 \\
Arms \& Ammunition & 0.09 & 0.08 & 0.00 & 0.00 & 0.01 &. & 0.03 \\
Articles of Stone, Plaster, Cement & 1.11 & 1.01 & 0.04 & 0.83 & 0.56 &. & 0.79 \\
Base metals \& Articles thereof & 3.98 & 7.45 & 0.37 & 1.30 & 7.78 &. & 5.09 \\
Chemical Products & 7.76 & 3.49 & 0.24 & 3.58 & 2.68 &. & 2.59 \\
Footwear, Headgear & 2.08 & 2.00 & 2.19 & 1.17 & 0.06 &. & 0.15 \\
Hides \& Skins & 0.88 & 1.53 & 0.28 & 0.34 & 0.39 &. & 0.16 \\
Instruments & 4.74 & 1.00 & 0.01 & 2.51 & 0.05 &. & 2.19 \\
Machinery \& Mechanical Appliances & 37.55 & 18.69 & 0.09 & 8.20 & 0.35 &. & 24.19 \\
Mineral Products & 6.43 & 26.06 & 50.47 & 17.02 & 49.61 &. & 12.43 \\
\hline
\end{tabular}




\begin{tabular}{lrrrrrrr}
\hline Miscellaneous & 4.86 & 2.12 & 0.23 & 0.59 & 0.46 &. & 2.85 \\
Plastics \& Rubber & 2.35 & 1.83 & 0.04 & 0.96 & 0.57 &. & 2.91 \\
Precious Stones, Metals, Coins & 1.54 & 7.11 & 0.82 & 1.20 & 4.10 &. & 2.41 \\
Prepared Foodstuffs & 1.38 & 2.98 & 0.72 & 3.89 & 2.59 &. & 1.71 \\
Special Classification Provisions & 3.55 & 1.88 & 0.81 & 3.07 & 4.37 &. & 5.56 \\
Textiles \& Textile Articles & 4.36 & 12.83 & 39.90 & 43.21 & 7.88 &. & 3.84 \\
Transportation Equipment & 14.01 & 2.58 & 0.00 & 0.09 & 0.04 &. & 23.43 \\
Vegetable Products & 0.31 & 2.18 & 1.55 & 8.42 & 13.83 &. & 1.27 \\
Wood \& Wood Products & 0.39 & 1.48 & 0.06 & 0.33 & 0.99 &. & 2.95 \\
Wood Pulp \& Products & 0.98 & 0.76 & 0.02 & 0.12 & 0.35 &. & 3.87 \\
Works of Art, Collector's Pieces \& Antiq & 0.81 & 0.20 & 0.14 & 0.06 & 0.09 &. & 0.05 \\
\hline \multicolumn{1}{c}{ Total } & 100.00100 .00 & 100.00 & 100.00 & 100.00 &. & 100.00 \\
\hline
\end{tabular}

Trade Shares Within Sector, by Preference Scheme Country Group, 2000

\begin{tabular}{lcccccrrr}
\hline \multicolumn{1}{c}{ European Union } & MFN & GSP & GSPLDC CBERA & ATPA & ACP & Other \\
\hline Animal or Veg. Fats, Oils \& Waxes & 15.0 & 60.3 & 0.0 &. &. & 11.5 & 13.1 \\
Animals \& Animal Products & 46.2 & 33.3 & 0.9 &. &. & 8.9 & 10.0 \\
Arms \& Ammunition & 77.8 & 10.3 & 0.0 &. &. & 0.1 & 7.0 \\
Articles of Stone, Plaster, Cement & 51.9 & 25.4 & 0.1 &. &. & 0.1 & 11.9 \\
Base metals \& Articles thereof & 50.7 & 32.5 & 0.0 &. &. & 1.6 & 10.2 \\
Chemical Products & 77.8 & 14.3 & 0.0 &. &. & 1.1 & 5.8 \\
Footwear, Headgear & 24.1 & 62.3 & 0.9 &. &. & 0.5 & 10.3 \\
Hides \& Skins & 24.8 & 65.9 & 0.9 &. &. & 2.2 & 5.4 \\
Instruments & 83.0 & 12.7 & 0.0 &. &. & 0.3 & 3.3 \\
Machinery \& Mechanical Appliances & 72.5 & 17.8 & 0.0 &. &. & 0.1 & 7.5 \\
Mineral Products & 26.4 & 54.0 & 0.0 &. &. & 5.5 & 13.5 \\
Miscellaneous & 38.8 & 44.0 & 0.0 &. &. & 0.2 & 12.5 \\
Plastics \& Rubber & 62.5 & 23.3 & 0.0 &. &. & 0.7 & 8.9 \\
Precious Stones, Metals, Coins & 53.9 & 25.7 & 0.0 &. &. & 12.8 & 7.2 \\
Prepared Foodstuffs & 33.5 & 37.8 & 0.1 &. &. & 21.9 & 6.1 \\
Special Classification Provisions &. &. &. &. &. &. &. \\
Textiles \& Textile Articles & 38.1 & 37.3 & 4.0 &. &. & 2.4 & 16.3 \\
Transportation Equipment & 76.8 & 9.6 & 0.0 &. &. & 2.1 & 6.9 \\
Vegetable Products & 27.9 & 49.7 & 0.1 &. &. & 11.5 & 10.2 \\
Wood \& Wood Products & 38.5 & 35.0 & 0.0 &. &. & 10.5 & 10.9 \\
Wood Pulp \& Products & 72.6 & 17.9 & 0.0 &. &. & 0.1 & 6.2 \\
Works of Art, Collectors Pieces \& Antiq & 95.6 & 2.9 & 0.0 &. &. & 0.3 & 0.9 \\
\hline \multicolumn{1}{c}{ Total } & 57.9 & 27.4 & 0.4 &. &. & 3.0 & 9.0 \\
\hline & & & & & &
\end{tabular}


Developed Country Trade Barriers and the Least Developed Countries: The Current Situation 263

Within Preference Scheme Country Group Trade Shares by Sector, 2000

\begin{tabular}{lrrrrrrrr}
\hline \multicolumn{1}{c}{ European Union } & MFN & GSP & GSPLDC CBERA & ATPA & ACP & Other \\
\hline Animal or Veg. Fats, Oils \& Waxes & 0.04 & 0.49 & 0.00 &. &. & 0.97 & 0.09 \\
Animals \& Animal Products & 1.26 & 1.99 & 4.84 &. &. & 5.41 & 1.56 \\
Arms \& Ammunition & 0.09 & 0.01 & 0.00 &. &. & 0.00 & 0.04 \\
Articles of Stone, Plaster, Cement & 0.75 & 0.80 & 0.32 &. &. & 0.03 & 1.48 \\
Base metals \& Articles thereof & 5.07 & 7.12 & 0.12 &. &. & 3.69 & 8.00 \\
Chemical Products & 8.79 & 3.39 & 0.08 &. &. & 2.28 & 3.67 \\
Footwear, Headgear & 0.44 & 2.53 & 2.78 &. &. & 0.15 & 0.95 \\
Hides \& Skins & 0.44 & 2.52 & 2.80 &. &. & 0.99 & 0.60 \\
Instruments & 6.24 & 1.75 & 0.01 &. &. & 0.31 & 1.14 \\
Machinery \& Mechanical Appliances & 36.93 & 18.76 & 0.41 &. &. & 0.54 & 23.41 \\
Mineral Products & 7.35 & 28.98 & 1.09 &. &. & 37.47 & 19.79 \\
Miscellaneous & 1.91 & 4.78 & 0.36 &. &. & 0.17 & 3.93 \\
Plastics \& Rubber & 3.03 & 2.39 & 0.18 &. &. & 0.73 & 3.49 \\
Precious Stones, Metals, Coins & 2.42 & 2.19 & 0.13 &. &. & 6.96 & 5.26 \\
Prepared Foodstuffs & 1.33 & 3.19 & 0.53 &. &. & 15.03 & 1.58 \\
Special Classification Provisions & 1.38 & 0.22 & 0.19 &. &. & 0.11 & 0.51 \\
Textiles \& Textile Articles & 4.79 & 9.12 & 83.79 &. &. & 6.23 & 9.02 \\
Transportation Equipment & 12.41 & 2.01 & 0.33 &. &. & 2.06 & 9.18 \\
Vegetable Products & 1.37 & 4.47 & 0.64 &. &. & 10.97 & 2.74 \\
Wood \& Wood Products & 1.13 & 2.01 & 1.29 &. &. & 5.80 & 1.98 \\
Wood Pulp \& Products & 2.37 & 1.26 & 0.08 &. &. & 0.08 & 1.55 \\
Works of Art, Collector's Pieces \& Antiq & 0.46 & 0.03 & 0.05 &. &. & 0.03 & 0.04 \\
\hline \multicolumn{1}{c}{ Total } & 100.00 & 100.00 & 100.00 &. &. & 100.00100 .00 \\
\hline
\end{tabular}

Trade Shares Within Sector, by Preference Scheme Country Group, 2000

\begin{tabular}{lcrrrrrr}
\hline \multicolumn{1}{c}{ Japan } & MFN & GSP & GSPLDC CBERA & ATPA & ACP & Other \\
\hline Animal or Veg. Fats, Oils \& Waxes & 43.8 & 55.9 & 0.3 &. &. &. &. \\
Animals \& Animal Products & 59.5 & 38.8 & 1.6 &. &. &. &. \\
Arms \& Ammunition & 99.7 & 0.3 & 0.0 &. &. &. &. \\
Articles of Stone, Plaster, Cement & 50.8 & 48.6 & 0.0 &. &. &. &. \\
Base metals \& Articles thereof & 47.2 & 52.8 & 0.0 &. &. &. &. \\
Chemical Products & 82.2 & 17.8 & 0.0 &. &. &. &. \\
Footwear, Headgear & 20.0 & 78.9 & 1.0 &. &. &. &. \\
Hides \& Skins & 50.4 & 49.2 & 0.3 &. &. &. &. \\
Instruments & 73.9 & 26.1 & 0.0 &. &. &. &. \\
Machinery \& Mechanical Appliances & 53.5 & 46.4 & 0.0 &. &. &. &. \\
Mineral Products & 17.6 & 82.2 & 0.2 &. &. &. &. \\
Miscellaneous & 43.0 & 56.9 & 0.0 &. &. &. &. \\
Plastics \& Rubber & 54.4 & 45.6 & 0.0 &. &. &. &. \\
Precious Stones, Metals, Coins & 55.3 & 44.7 & 0.0 &. &. &. &. \\
Prepared Foodstuffs & 58.1 & 41.6 & 0.3 &. &. &. &. \\
\hline
\end{tabular}




\begin{tabular}{lrrrrrrc}
\hline Special Classification Provisions &. &. &. &. &. &. &. \\
Textiles \& Textile Articles & 19.0 & 80.8 & 0.2 &. &. &. & . \\
Transportation Equipment & 92.8 & 7.2 & 0.0 &. &. &. &. \\
Vegetable Products & 63.1 & 35.5 & 1.2 &. &. &. &. \\
Wood \& Wood Products & 55.4 & 44.1 & 0.4 &. &. &. &. \\
Wood Pulp \& Products & 78.8 & 21.2 & 0.0 &. &. &. &. \\
Works of Art, Collector's Pieces \& Antiq & 86.3 & 13.2 & 0.4 &. &. &. &. \\
\hline \multicolumn{1}{c}{ Total } & 49.8 & 49.9 & 0.3 &. &. &. &. \\
\hline
\end{tabular}

Within Preference Scheme Country Group Trade Shares by Sector, 2000

\begin{tabular}{|c|c|c|c|c|c|c|c|}
\hline Japan & MFN & GSP & GSPLDC & CBERA & ATPA & $\mathrm{ACP}$ & Other \\
\hline Animal or Veg. Fats, Oils \& Waxes & 0.18 & 0.23 & 0.27 & . & . & . & . \\
\hline Animals \& Animal Products & 8.24 & 5.35 & 42.60 & . & . & . & . \\
\hline Arms \& Ammunition & 0.08 & 0.00 & 0.00 & . & . & . & . \\
\hline Articles of Stone, Plaster, Cement & 0.84 & 0.80 & 0.06 & . & . & . & . \\
\hline Base metals \& Articles thereof & 4.06 & 4.53 & 0.26 & . & . & . & . \\
\hline Chemical Products & 11.24 & 2.42 & 0.01 & . & . & . & . \\
\hline Footwear, Headgear & 0.44 & 1.74 & 4.03 & . & . & . & . \\
\hline Hides \& Skins & 1.16 & 1.13 & 1.52 & . & . & . & . \\
\hline Instruments & 6.69 & 2.35 & 0.68 & . & . & . & . \\
\hline Machinery \& Mechanical Appliances & 24.72 & 21.38 & 1.07 & . & . & . & . \\
\hline Mineral Products & 6.67 & 31.01 & 13.74 & . & . & . & . \\
\hline Miscellaneous & 2.09 & 2.75 & 0.37 & . & . & . & . \\
\hline Plastics \& Rubber & 2.29 & 1.92 & 0.01 & . & . & . & . \\
\hline Precious Stones, Metals, Coins & 2.33 & 1.87 & 0.12 & . & . & . & . \\
\hline Prepared Foodstuffs & 5.22 & 3.73 & 4.67 & . & . & . & . \\
\hline Special Classification Provisions & . & . & . & . & . & . & . \\
\hline Textiles \& Textile Articles & 2.63 & 11.16 & 5.13 & . & . & . & . \\
\hline Transportation Equipment & 9.21 & 0.71 & 0.01 & . & . & . & . \\
\hline Vegetable Products & 5.58 & 3.13 & 19.84 & . & . & . & . \\
\hline Wood \& Wood Products & 4.04 & 3.20 & 5.32 & . & . & . & . \\
\hline Wood Pulp \& Products & 2.05 & 0.55 & 0.08 & . & . & . & . \\
\hline Works of Art, Collector's Pieces \& Antiq & 0.26 & 0.04 & 0.22 & . & . & . & . \\
\hline Total & 100.00 & 100.00 & 100.00 & . & . & . & . \\
\hline
\end{tabular}


Developed Country Trade Barriers and the Least Developed Countries: The Current Situation 265

\section{Appendix F}

Import-weighted Average Tariffs by Program and Commodity Group

Table F1. United States

\begin{tabular}{lccccccc}
\hline & MFN & GSP & GSPLDC & ANDEANCBERA ACP OTHER \\
\hline Animal or Veg. Fats, Oils \& Waxes & 0.64 & 0.25 & 0.00 & 0.00 & 0.00 &. & 0.00 \\
Animals \& Animal Products & 4.60 & 0.58 & 0.00 & 0.00 & 0.27 &. & 0.68 \\
Arms \& Ammunition & 1.29 & 0.01 & 0.31 & 0.00 & 0.00 &. & 0.00 \\
Articles of Stone, Plaster, Cement & 5.53 & 3.14 & 0.03 & 0.00 & 0.00 &. & 0.61 \\
Base metals \& Articles thereof & 2.57 & 0.86 & 0.98 & 0.67 & 0.00 &. & 0.10 \\
Chemical Products & 2.81 & 0.99 & 0.00 & 0.80 & 1.45 &. & 0.02 \\
Footwear, Headgear & 12.13 & 9.80 & 7.48 & 5.70 & 8.02 &. & 2.05 \\
Hides \& Skins & 7.64 & 6.52 & 10.06 & 3.45 & 5.34 &. & 0.81 \\
Instruments & 1.41 & 0.62 & 0.09 & 0.00 & 0.00 &. & 0.00 \\
Machinery \& Mechanical Appliances & 0.72 & 0.14 & 0.10 & 0.00 & 0.00 &. & 0.00 \\
Mineral Products & 5.26 & 0.94 & 0.00 & 0.00 & 0.00 &. & 0.02 \\
Miscellaneous Manufactured Articles & 1.16 & 0.26 & 0.57 & 0.01 & 0.01 &. & 0.00 \\
Plastics \& Rubber & 3.73 & 0.51 & 0.01 & 0.71 & 0.00 &. & 0.01 \\
Precious Stones, Metals, Coins & 2.10 & 0.20 & 0.44 & 0.17 & 0.00 &. & 0.00 \\
Prepared Foodstuffs & 4.89 & 7.01 & 31.52 & 3.45 & 2.42 &. & 0.65 \\
Special Classification Provisions &. &. &. &. &. &. &. \\
Textiles \& Textile Articles & 11.03 & 11.59 & 11.61 & 13.66 & 11.76 &. & 0.15 \\
Transportation Equipment & 2.07 & 0.18 & 0.00 & 0.00 & 0.00 &. & 0.01 \\
Vegetable Products & 1.61 & 2.97 & 0.01 & 0.42 & 0.22 &. & 0.18 \\
Wood \& Wood Products & 2.20 & 0.99 & 0.54 & 0.09 & 0.04 &. & 0.00 \\
Wood Pulp \& Products & 0.67 & 0.00 & 0.01 & 0.00 & 0.00 &. & 0.00 \\
Works of Art, Collector's Pieces \& Antiq & 0.00 & 0.00 & 0.00 & 0.00 & 0.00 &. & 0.00 \\
\hline
\end{tabular}

Table F2. European Union

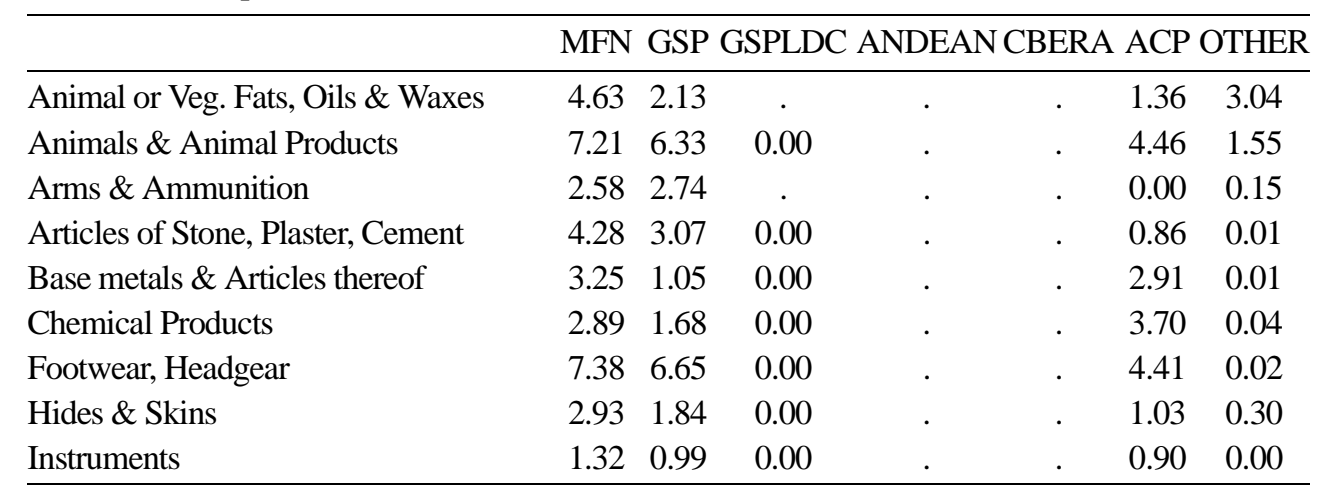


Table F2. Continued

\begin{tabular}{|c|c|c|c|c|c|c|c|}
\hline Machinery \& Mechanical Appliances & 1.18 & 0.78 & 0.00 & & . & 0.51 & 0.01 \\
\hline Mineral Products & 0.29 & 0.01 & 0.00 & . & . & 0.00 & 0.00 \\
\hline Miscellaneous Manufactured Articles & 2.02 & 1.11 & 0.00 & . & . & 0.87 & 0.00 \\
\hline Plastics \& Rubber & 5.63 & 1.49 & 0.00 & . & . & 0.34 & 0.02 \\
\hline Precious Stones, Metals, Coins & 0.19 & 0.07 & 0.00 & . & . & 0.00 & 0.00 \\
\hline Prepared Foodstuffs & 9.51 & 6.06 & 0.00 & . & . & 6.55 & 4.72 \\
\hline Special Classification Provisions & . & - & . & . & . & . & . \\
\hline Textiles \& Textile Articles & 10.10 & 8.92 & 0.00 & . & $\cdot$ & 6.25 & 0.09 \\
\hline Transportation Equipment & 5.68 & 4.04 & 0.00 & . & • & 0.10 & 0.03 \\
\hline Vegetable Products & 3.58 & 3.27 & 0.09 & . & . & 4.06 & 3.13 \\
\hline Wood \& Wood Products & 1.18 & 1.05 & 0.00 & . & . & 0.19 & 0.04 \\
\hline Wood Pulp \& Products & 1.37 & 0.19 & 0.00 & . & . & 0.28 & 0.00 \\
\hline Works of Art, Collector's Pieces \& Antiq & 0.00 & 0.00 & 0.00 & . & . & 0.00 & 0.00 \\
\hline
\end{tabular}

Table F3. Japan

\begin{tabular}{lccccccc}
\hline & MFN & GSP & GSPLDC & ANDEAN & CBERA & ACP OTHER \\
\hline Animal or Veg. Fats, Oils \& Waxes & 2.36 & 1.17 & 0.00 &. &. &. &. \\
Animals \& Animal Products & 16.37 & 4.27 & 3.89 &. &. &. &. \\
Arms \& Ammunition & 11.06 & 1.03 &. &. &. &. &. \\
Articles of Stone, Plaster, Cement & 1.55 & 0.12 & 0.00 &. &. &. &. \\
Base metals \& Articles thereof & 1.50 & 0.89 & 0.00 &. &. &. &. \\
Chemical Products & 2.43 & 0.74 & 0.00 &. &. &. &. \\
Footwear, Headgear & 36.09 & 9.75 & 0.05 &. &. &. &. \\
Hides \& Skins & 12.27 & 7.18 & 0.08 &. &. &. &. \\
Instruments & 0.07 & 0.10 & 0.00 &. &. &. &. \\
Machinery \& Mechanical Appliances & 0.05 & 0.01 & 0.00 &. &. &. &. \\
Mineral Products & 0.17 & 0.35 & 0.61 &. &. &. &. \\
Miscellaneous Manufactured Articles & 1.15 & 0.16 & 0.00 &. &. &. &. \\
Plastics \& Rubber & 3.85 & 0.88 & 0.00 &. &. &. &. \\
Precious Stones, Metals, Coins & 1.33 & 0.10 & 0.00 &. &. &. &. \\
Prepared Foodstuffs & 14.1210 .53 & 0.10 &. &. &. &. \\
Special Classification Provisions &. &. &. &. &. &. &. \\
Textiles \& Textile Articles & 9.31 & 5.50 & 0.61 &. &. &. &. \\
Transportation Equipment & 0.05 & 0.00 & 0.00 &. &. &. &. \\
Vegetable Products & 14.61 & 5.86 & 0.11 &. &. &. &. \\
Wood \& Wood Products & 1.46 & 2.45 & 0.03 &. &. &. &. \\
Wood Pulp \& Products & 0.41 & 0.62 & 0.81 &. &. &. &. \\
Works of Art, Collector's Pieces \& Antiq & 0.00 & 0.00 & 0.00 &. &. &. &. \\
\hline
\end{tabular}




\section{Appendix G}

Country Listing(LDCs in Bold)

\begin{tabular}{|c|c|c|c|c|c|}
\hline Africa & Asia & Europe & $\begin{array}{c}\text { Latin \& S. } \\
\text { America }\end{array}$ & $\begin{array}{c}\text { Middle } \\
\text { East }\end{array}$ & $\begin{array}{c}\text { North } \\
\text { America }\end{array}$ \\
\hline Algeria & Austrlia & Austria & Mexico & Bahrain & Canada \\
\hline Botswana & Japan & Belgium & Anguila & Cyprus & United States \\
\hline BouvetIs & Korea & Denmark & Antigua & Egypt & Bermuda \\
\hline Cameroon & New.Zlnd & Finland & Argntina & Iran & Greenland \\
\hline Congo & AmerSmoa & France & Aruba & Iraq & St P.Miq \\
\hline C.Ivoire & Brunei & Germany & Bahamas & Israel & \\
\hline Gabon & BrInOcTr & Italy & Barbados & Jordan & \\
\hline Ghana & China & Nethlnds & Belize & Kuwait & \\
\hline Kenya & China.TW & Norway & Bolivia & Lebanon & \\
\hline Maurtius & ChristIs & Portugal & Brazil & Liby.Ar & \\
\hline Morocco & CocosIsl & Spain & BrVrgnIs & Oman & \\
\hline Namibia & CookIsls & Sweden & CaymanIs & Qatar & \\
\hline Nigeria & EastTimr & Untd.Kgd & Chile & SaudiArb & \\
\hline Samoa & Fiji & Albania & Colombia & Syria & \\
\hline Seychlls & FrPolyns & Andorra & CostaRca & UAEmirat & \\
\hline Swazilnd & Guam & Armenia & Cuba & Yemen & \\
\hline SAfrica & HongKong & Azrbaijn & Dominica & & \\
\hline Tunisia & India & Belarus & DominRep & & \\
\hline Zimbabwe & Indnesia & BosniaHe & Ecuador & & \\
\hline W.Sahara & JohnIsl & Bulgaria & ElSalvdr & & \\
\hline Angola & Korea.DP & CHANNL. & FlklndIs & & \\
\hline Benin & Macau & Croatia & FrGuiana & & \\
\hline BurkFaso & Malaysia & Czechrep & Grenada & & \\
\hline Burundi & Marshall & Estonia & Guadloup & & \\
\hline CapeVrde & Micrones & FaeroeIs & Guatmala & & \\
\hline Chad & Midway & Georgia & Guyana & & \\
\hline Comoros & Mongolia & Gibrltar & Honduras & & \\
\hline C.AfrRep & Nauru & Greece & Jamaica & & \\
\hline Djibouti & NewCaldo & HolySee & Martnque & & \\
\hline Eq.Guin & Niue & Hungary & Montsrrt & & \\
\hline Eritrea & NorflkIs & Iceland & Neth.Ant & & \\
\hline Ethiopia & NMariana & Ireland & Nicargua & & \\
\hline Gambia & PacficIs & IsleOMan & Panama & & \\
\hline GneaBiss & Pakistan & Kazakhst & Paraguay & & \\
\hline Guinea & PapNGuin & Kyrgyzst & Peru & & \\
\hline Lesotho & Philippi & Latvia & PrtoRico & & \\
\hline Liberia & Pitcairn & Liechstn & StHelena & & \\
\hline Madagscr & Singapor & Lithuani & StKitts & & \\
\hline Malawi & Vietnam & Luxmborg & StLucia & & \\
\hline
\end{tabular}




\begin{tabular}{cccc}
\hline Mali & SriLanka & Malta & StVincnt \\
Maurtnia & Thailand & Moldova & Suriname \\
Mozmbque & Tokelau & Monaco & Trinidad \\
Niger & Tonga & Poland & TurksIsl \\
Rwanda & WakeIsln & Romania & Uruguay \\
Senegal & WallisIs & Russia & USVirgIs \\
SierraLe & Samoa & SnMarino & Venzuela \\
Somalia & Afghnstn & Slovenia & Haiti \\
SaoTome & Bangldsh & Svalbard & \\
Sudan & Bhutan & Switzrld \\
Togo & Cambodia & Tajikist \\
Uganda & Kiribati & Turkey \\
Tanzania & Lao.Pdr & Turkmeni \\
Zaire & Maldives & Ukraine \\
Zambia & Myanmar & Uzbekist \\
& Nepal & Yugoslav \\
& Solomons & Macdonia \\
& Tuvalu & Slovakia \\
& Vanuatu & \\
\hline
\end{tabular}

\section{Appendix $\mathbf{H}$}

Triad Tariffs on LDC Imports by Region and Commodity, 2000 (Importweighted Averages)

Table H1. U.S. Tariffs on LDC Imports

\begin{tabular}{|c|c|c|c|c|c|c|c|c|}
\hline & \multicolumn{4}{|c|}{$\begin{array}{l}\text { US Tariffs on LDC Imports } \\
\text { by Region and Commodity }\end{array}$} & \multicolumn{4}{|c|}{$\begin{array}{l}\text { The Distribution of US Imports } \\
\text { From LDCs by Region and } \\
\text { Commodity }\end{array}$} \\
\hline & A frica & Asia & $\begin{array}{c}\text { Latin } \\
\text { America }\end{array}$ & $\begin{array}{l}\text { Middle } \\
\text { East }\end{array}$ & Africa & Asia & $\begin{array}{l}\text { Latin } \\
\text { America }\end{array}$ & $\begin{array}{l}\text { Middle } \\
\text { East }\end{array}$ \\
\hline Animal or Veg. Fats, Oils \& Waxes & 0.00 & 0.00 & 0.00 & . & 0.0 & 0.0 & 0.1 & . \\
\hline Animals \& Animal Products & 0.00 & 0.00 & 0.00 & 0.00 & 0.3 & 4.5 & 1.3 & 0.1 \\
\hline Arms \& Ammunition & . & 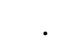 & . & . & . & . & . & . \\
\hline Articles of Stone, Plaster, Cement & 0.44 & 0.02 & 0.00 & 0.00 & 0.0 & 0.1 & 0.3 & 0.0 \\
\hline Base metals \& Articles there of & 0.98 & 0.69 & 0.00 & . & 0.7 & 0.0 & 1.2 & . \\
\hline Chemical Products & 0.00 & 0.00 & 0.00 & . & 0.2 & 0.3 & 0.2 & . \\
\hline Footwear, Headgear & 1.27 & 7.49 & 0.43 & . & 0.0 & 4.6 & 0.2 & . \\
\hline Hides \& Skins & 1.55 & 10.73 & 0.19 & . & 0.0 & 0.7 & 1.5 & . \\
\hline Instruments & 0.10 & 0.14 & 0.00 & . & 0.0 & 0.0 & 0.0 & . \\
\hline Machinery \& Mechanical Appliances & 0.32 & 0.14 & 0.00 & 0.00 & 0.2 & 0.1 & 0.6 & 0.0 \\
\hline
\end{tabular}


Developed Country Trade Barriers and the Least Developed Countries: The Current Situation 269

Table H1. Continued

\begin{tabular}{lcccccccc}
\hline Mineral Products & 0.00 &. & 0.00 & 0.00 & 85.9 &. & 0.0 & 98.1 \\
Miscellaneous M anufactured Articles & 0.01 & 0.56 & 0.02 &. & 0.0 & 0.5 & 1.6 &. \\
Plastics \& Rubber & 0.00 & 0.09 & 0.00 & 1.52 & 1.0 & 0.1 & 0.1 & 0.0 \\
Precious Stones, Metals, Coins & 0.24 & 0.03 & 0.00 & 0.00 & 1.3 & 0.4 & 0.0 & 0.0 \\
Prepared Foodstuffs & 31.76 & 3.92 & 0.11 &. & 1.4 & 0.1 & 0.5 &. \\
Textiles \& Textile Articles & 11.61 & 11.94 & 14.67 & 7.70 & 5.9 & 88.2 & 89.1 & 0.0 \\
Transportation Equipment & 0.00 & 0.10 & 0.00 & 0.00 & 0.0 & 0.0 & 0.0 & 0.0 \\
Vegetable Products & 0.00 & 0.11 & 0.00 & 0.00 & 2.9 & 0.1 & 2.8 & 1.3 \\
Wood \& Wood Products & 0.44 & 0.91 & 0.46 &. & 0.1 & 0.2 & 0.1 &. \\
Wood Pulp \& Products & 0.00 & 0.00 & 0.00 & 0.00 & 0.0 & 0.0 & 0.2 & 0.0 \\
Works of Art, Collector's Pieces \& Antiq & 0.00 & 0.00 & 0.00 & 0.00 & 0.1 & 0.1 & 0.1 & 0.5 \\
\hline
\end{tabular}

Table H2. EU Tariffs on LDC Imports

\begin{tabular}{|c|c|c|c|c|c|c|c|c|}
\hline & \multicolumn{4}{|c|}{$\begin{array}{l}\text { EU Tariffs on LDC Imports } \\
\text { by Region and Commodity }\end{array}$} & \multicolumn{4}{|c|}{$\begin{array}{l}\text { The Distribution of EU Imports } \\
\text { From LDCs by Region and } \\
\text { Commodity }\end{array}$} \\
\hline & Africa & Asia & $\begin{array}{c}\text { Latin } \\
\text { America }\end{array}$ & $\begin{array}{l}\text { Middle } \\
\text { East }\end{array}$ & A frica & Asia & $\begin{array}{c}\text { Latin } \\
\text { America }\end{array}$ & $\begin{array}{l}\text { Middle } \\
\text { East }\end{array}$ \\
\hline Animal or Veg. Fats, Oils \& Waxes & 1.98 & 0.00 & 0.00 & · & 1.4 & 0.1 & 0.0 & $\cdot$ \\
\hline Animals \& Animal Products & 2.08 & 0.00 & 0.07 & 0.00 & 10.8 & 4.7 & 0.6 & 12.4 \\
\hline Arms \& Ammunition & 0.00 & . & . & . & 0.0 & . & . & . \\
\hline Articles of Stone, Plaster, Cement & 0.06 & 0.00 & 0.00 & . & 0.1 & 0.3 & 0.1 & . \\
\hline Base metals \& Articles there of & 0.01 & 0.00 & 0.00 & 0.00 & 1.9 & 0.1 & 0.8 & 1.1 \\
\hline Chemical Products & 0.00 & 0.00 & 0.00 & 0.00 & 0.8 & 0.1 & 17.5 & 0.3 \\
\hline Footwear, Headgear & 0.44 & 0.00 & 0.00 & . & 0.2 & 2.8 & 0.2 & . \\
\hline Hides \& Skins & 0.09 & 0.00 & 0.00 & 0.00 & 1.7 & 2.7 & 0.0 & 6 \\
\hline Instruments & 0.16 & 0.00 & 0.00 & . & 0.2 & 0.0 & 0.2 & . \\
\hline Machinery \& Mechanical Appliances & 0.07 & 0.00 & 0.00 & 0.00 & 0.4 & 0.3 & 0.2 & 7.2 \\
\hline Mineral Products & 0.00 & 0.00 & 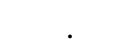 & 0.00 & 35.0 & 0.0 & . & 63.6 \\
\hline Miscellaneous Manufactured Articles & 0.00 & 0.00 & 0.00 & 0.00 & 0.1 & 0.4 & 0.6 & 0 \\
\hline Plastics \& Rubber & 0.02 & 0.00 & . & 0.00 & 0.2 & 0.2 & . & 0.1 \\
\hline Precious Stones, Metals, Coins & 0.00 & 0.00 & . & 0.00 & 15.2 & 0.0 & . & 7.2 \\
\hline Prepared Foodstuffs & 3.66 & 0.04 & 0.00 & . & 1.7 & 0.7 & 8.1 & . \\
\hline Textiles \& Textile Articles & 0.00 & 0.00 & 0.00 & 0.00 & 8.8 & 85.0 & 5.1 & 1.1 \\
\hline Transportation Equipment & 0.02 & 0.00 & 0.00 & 0.00 & 4.5 & 0.3 & 0.2 & 0.6 \\
\hline Vegetable Products & 0.13 & 0.08 & 0.02 & 0.00 & 14.0 & 0.8 & 63.8 & 0.3 \\
\hline Wood \& Wood Products & 0.01 & 0.00 & 0.00 & . & 3.0 & 1.3 & 1.2 & . \\
\hline Wood Pulp \& Products & 0.00 & 0.00 & 0.00 & 0.00 & 0.1 & 0.1 & 0.5 & 0.1 \\
\hline Works of Art, Collector's Pieces \& Antiq & 0.00 & 0.00 & 0.00 & 0.00 & 0.0 & 0.1 & 0.9 & 0.1 \\
\hline
\end{tabular}


Table H3. Japanese Tariffs on LDC Imports

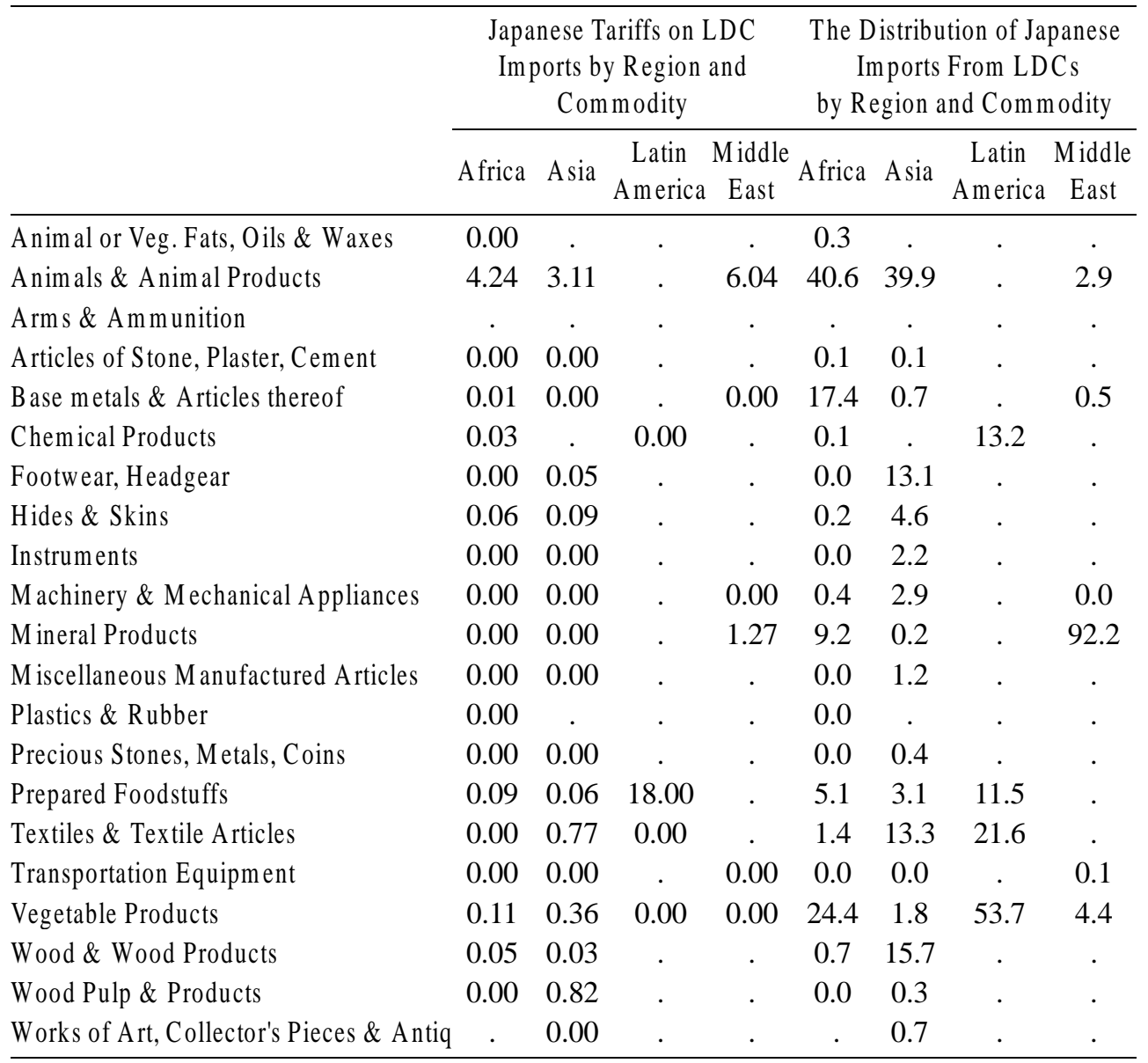

